

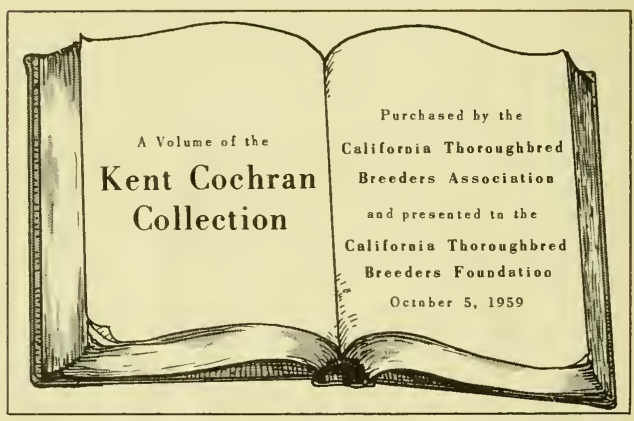




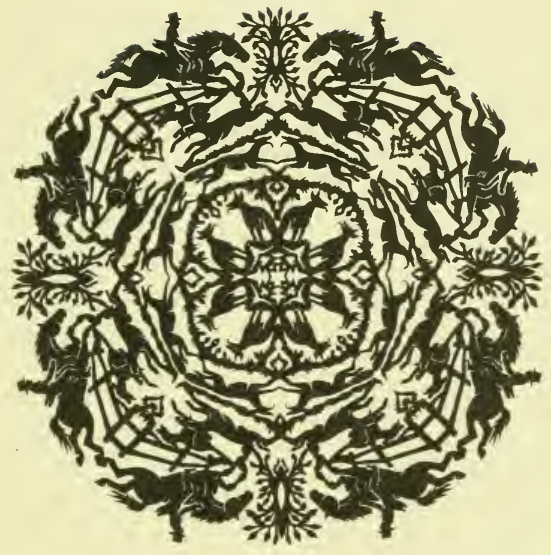

JOHN A.SEAVERNS 






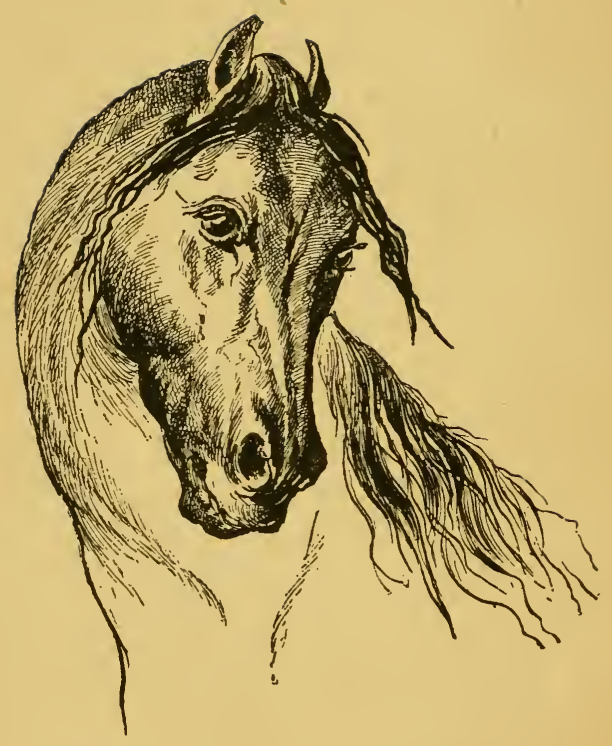

HEAD OF TYPICAL ARABIAN HORSE. 


\section{MY HORSE; MY LOVE}

"His neigh is like the bidding of a monarch, and his countenance enforces homage."-KING HENRY $V$.

BY

\section{DINAH SHARPE}

AUTHOR OF "THE APPLE OF ARABIA'S EYE," AND OTHER GTORIES

I L L U STR A T E D

NEW YORK

ORANGE JUDD COMPANY

I892 
COPYRIGHT, $189 z$, BY SARA BUCKMAN LINARD. 
To

MY DAUGHTERS

\section{VIRNIE AND MARGUERITE,}

THIS BOOK IS MOST I.OVINGLY

Inseribed. 



\section{CONTENTS.}

Introduction,

CHAPTER I.

Veterinary Education, • • • • . • . I 2

CHAPTER II.

Facilities for Breeding in America, . . . . . I8

CHAPTER III.

The Sense of Smell in the Horse, . . . . . 22

CHAPTER IV.

Nature's Vinaigrette, . . . . . . . 25

CHAPTER V.

Arabia,

CHAPTER V.

CHAPTER VI.

Famous Arabian Horses, • • . . . . 38

CHAPTER VII.

Pedigree of Arabian Horses, • • • • . 45

CHAPTER VIII.

It is the Blood that Tells, . . . . . . 52

CHAPTER IX.

Types of Arabian Horses, , . . . . . . 55 
CHAPTER $\mathrm{X}$.

Arabian Horses in England,

CHAPTER XI.

English and Russian Horses, . . . . . . 65

CHAPTER XII.

Cruelty of Docking, . . . . . . . 7 I

CHAPTER XIII.

Operation of Docking,

CHAPTER XIV.

The Mexican Bit and Curb, . . . . . . 8I

CHAPTER XV.

The Bearing-Rein,

CHAPTER XVI.

Balking,

CHAPTER XVII.

Blinkers and Blindness, . . . . . . . 96

CHAPTER XVIII.

Teeth and Toothache,

CHAPTER XIX.

Lockjaw,

CHAPTER XX.

Arab Horses in South America,

CHAPTER XXI.

Arab Horses in North America, 
CHAPTER XXII.

Secretary Seward's Arabs, . . . . . . II8

CHAPTER XXIII.

Selim,

Selim,

Abdallah,

CHAPTER XXIV.

CHAPTER XXV.

\section{The American Horse \\ CHAPTER XXVI.}

“Standard Bred" Horses,

CHAPTER XXVII.

General Grant's Horses,

CHAPTER XXVIII.

Americo-Arab Stud,

CHAPTER XXIX.

Conclusion, 



\section{MY HORSE; MY LOVE.}

\section{INTRODUCTION.}

"Aн, this is delightful," exclaimed the Count, as he held his hands toward the cheerful blaze of a bright wood fire, on our broad old hearthstone.

The Count had come to make us a long-promised visit in the early autumn; arriving at the twilight hour of a dreary day, chill and bleak, with a persistent soaking rain, and a gusty, soughing wind. For one long week the sun had hidden his face behind the dull and sodden sky, depriving us of the solace even of a brisk walk, or a game at tennis, in these last days of our summer sojourn by the seaside. So we heard the roar of the ocean, and the howling wind outside, with a pleasing sense of comfort in the contrast, as we watched the wide flames, now shooting up with a noisy crackling energy, now dying down to a hissing mysterious whisper.

Conversation was brisk, for the Count had such an inexhaustible fund of romance, fact, story, and adventure, that we gave him little chance of rest when an adroit question, here and there, inspired him to tell us of his past life. A Polish patriot- 
the last of the noble family of Kosciusko-his studied English and quaint accent added greatly to the interest of his narrations.

As he had promised to tell us the "why and wherefore" of his residence in America, with a final poke at the fire the little war of question and reply began.

THE COUNT.

You have promised, Count, to give us some particulars of your life in Russia. Since you were born in Poland, did you serve in the Russian army by choice?

"Poland being subject to Russia, I had no choice but to serve in the Russian army. It would be a life-long reproach to his courage and patriotism, if a nobleman, born in Poland, without physical deformity, and strong in limb and wind, should fail to devote some years of his life to military service. He would be stripped of his title of nobility, and could arrive at no personal distinction of an honorable character."

I have always heard that Poland is a nation of soldiers.

"It is true-the government being controlled by old soldiers rather than by statesmen. Although diplomacy in foreign countries is studied as are the learned professions; in Poland it must be learned through the use of the sword, by military rule and suggestion. A man must at least prove himself a brave soldier, before he can serve the government as a diplomatist, or in any other capacity." 
Being on the Emperor's staff you were, of course, very near his person.

"Ah, madam, many a time have I put him in his kibitka and sent him home more drunk than any lord!"

Was Alexander II. an agreeable person to be on such intimate terms with?

"When sober, no man could be kinder, gentler, or more humane; but when drunk, he was worse than a wild beast, and developed characteristics which made him a terror to everybody near him. He would order a man's head chopped off for the least offence, or to suit his drunken whim, and did not mind standing by to see the order executed, while laughing in fiendish glee at the victim's terror."

Then you were not sorry to join the Polish insurrection against Russia?

"It was Poland that I loved, my own country, and it was my duty to fight for her and my pleasure also. We longed for liberty, and fought for it desperately. But Russia is a powerful nation, and we were outnumbered. I was thrown into an Austrian prison, where I remained four months and was then ordered to be sent to Russia. Knowing something of what torture awaited me there, and finding friends in the prison who were in communication with friends outside, I determined to make my escape."

How did you manage that?

"The bars of my cell had been cut, and hearing the signal agreed upon, I emerged from the window, and found it not too difficult a matter to leap to the parapet, then to the bastion, to another parapet, to a 
bastion below, and so on until I had descended low enough to make the plunge into the river. Swimming about 4,000 yards, I reached the opposite side just as the signal gun gave voice that a prisoner had escaped."

And you were not recaptured?

"As I reached the shore a friend seized my hand and ran with me to a carriage in waiting. Dry clothing, food, and brandy had been provided, but we tarried not. The good horses flew over the ground toward Bavaria, and once over its friendly borders I was again a free man."

Did you remain long in Bavaria?

"Not long. As soon as I had rested I went to Switzerland and thence to Rome."

In Rome you must have felt quite safe.

"Eternal watchfulness is the price of liberty. While walking there one evening, I had just turned into a quiet street when I was attacked by three lazzaroni. Being always armed, I quickly disabled two of them with my sword, and seizing the third, demanded of him the writing which gave him the authority to pursue me. The beggarly scoundrel, crying for mercy, handed it to me, when I knocked him flat and unconscious with my fist; just then a man came forward eagerly saying: 'Have you killed him? then give me back the paper!' It was a Russian detective who spoke, whom I recognized, and I determined not to spare him. Holding the paper toward him, as he put out his hand to take it, I stabbed him to the heart."

But were you not afraid of arrest? 
"With my bloody sword in one hand, and the paper in the other, containing a description of my person, and an order to seize me dead or alive, I went to the police authorities. I showed them the paper, told them of the assault upon me, and where they could find the dead body in the street, and possibly the three lazzaroni. Instead of arresting me, they applauded my deed, allowing me to go free. As I was soon thereafter warned by Cardinal Franchi and the Countess Odescalchi, née Pototska, of noble Polish birth, of another conspiracy against me, I left Rome for Paris, when my life was again attempted by a Russian spy."

But why should they seek to kill you?

"The Russian detective has the privilege of killing his victim if he can catch him in no other way. Finding Napoleon unfriendly, or at least indifferent, I returned to Switzerland. Here I was waited on by emissaries from Alexander, who offered to restore to me my entire property-which he had confiscated -and all my other rights, if I would swear to bend the knee to him and become once more his bodyguard."

You liked the Emperor, did you not?

"Ah, madam, the Russians are a nation of liars, and I loved my freedom too well to put it again in jeopardy. Knowing that even now these messengers of the Emperor had secret power to enforce his commands, I asked for a few hours in which to arrange some affairs. Fancying that they had met with less opposition than they expected, they readily and courteously acceded to my request. I wasted no time, 
but escaping from the house, reached the railroad station just as the fast train toward Liverpool and America came in sight. My securities had been changed into gold which I carried on my person, and so, with about sixty thousand dollars and my profession, I began life in America with a glad heart, rejoicing in the freedom which this brave land gives to all who dwell within its boundaries."

Then here you were, of course, free from persecution?

"Alas, no! Russian power and hostility are farreaching, and the secret spies of the Russian government have long arms. They are ubiquitous, and to the shame even of New York, be it said, that within that city exists a secret agency for Russian spies."

Is it possible that anything so iniquitous can be tolerated in our land?

"The fact can be easily proved. I had not been here long before the amusing information was brought me that I had been burned in effigy in Russia. But when I learned that my mother and sister had been imprisoned, and finally put to death by strangulation because, not knowing, they could not yield the secret of my hiding-place, the last link that bound my respect and alliance to Russia was broken, and my heart knew its first great sorrow."

\section{PERSECUTION.}

With such a cruel memory of Russia's wicked revenge, in the slaughter of your mother and sister, you must have been glad to adopt America as your 
future home. Of course no further attempts were made on your life here?

"On the contrary, three separate times my life has been in danger from Russian spies, and twice my good dog has warned and saved me."

Was it Beppo who saved your life?

"No, it was a noble English pointer, trained to perfection, whose love for and devotion and obedience to me were priceless, and his death a positive grief. Beppo, though a fine mastiff, is not his equal."

How did the dog save your life?

"Shortly after my arrival in North America eighteen years ago, the first attempt upon my life in this country was made. I had been reading until a late hour, but feeling weary, finally turned off the gas and went to bed. The resting-place of my English pointer at night was at my bedside. Suddenly, through the deep slumber in which I lay, sounded a low ominous growl, unusual enough to startle me into partial wakefulness. At my command the dog jumped on the bed, and feeling then secure, I closed my eyes, only to open them again in a moment, to see a man standing before me. In one hand he held up a lighted match, and in the other a poniard lifted high, and about to descend with unerring stroke upon me. With one bound my brave dog was upon him, and bore him to the floor; while, I, in striving to wrench the poniard from his hand, broke his arm."

The wretch! Then you were able to secure him?

"I bound him fast, and telling the dog to watch him, dressed hastily, and securing a firm hold on my 
midnight assassin, marched him off to the police station. There I told my story of his attempt upon my life and saw my affidavit written down, while in the bright light I recognized a certain Russian spy from the third chamber of government detectives."

You mean to say you recognized a spy from Russia in a police station in America?

"Certainly, madam."

Then they were in collusion to take your life!

"Doubtless. Leaving the poniard as a proof and witness against the spy, I was told to come in the morning. Incredible as it may seem, when I went the next day, instead of the ready recognition I had every right to expect, I was met by the stolid, indifferent question, 'Who are you?' I answered the query by asking another: "Where is the man, the murderer, I brought here last night with a broken arm and the poniard he meant to slay me with?' They vouchsafed me no other answer than 'We know nothing about him.' I asked for the book in which I had seen the record written, but only a frayed edge of paper indicated where it had been torn out, and even the blotter was destroyed."

What did you do and say?

"In deepest indignation I realized that bribery and lies had triumphed, and that the spy had been allowed to escape. Turning to the officer I said, 'You see this pistol and these cartridges with which I load it, and this knife? These arms I carry in self-defence, and the next time I bring you, not broken bones, but a dead man.' "' 
Had you at that time been made an American citizen?

"No, madam. And it was not until I realized that twice again my life was in danger, that I recognized the importance of placing myself under the protection of this great nation."

Where else, and how were you in danger?

"For a short time I lived in New Haven, and standing one day in my own grounds before my door, I saw a man enter the gate. He approached me and, with more politeness than one expects in a beggar, he asked for alms. Although he spoke Polish, it was with the Russian dialect, which betrayed him, and my suspicions were at once aroused. Regarding him keenly I was convinced that his errand was not one of mercy, and said to him: 'You beg, but your hands have never worked. Go to the kitchen and get your dinner, and here is fifty cents. You see this gun and this dog, and you understand that I know how to protect myself. If you are still here after the next train leaves, I will blow out your brains!' "'

And did this man again attempt your life?

"Not this one, but another. A few days later, as I watched some stone-masons at work on a church, I was struck by the exceeding awkwardness of one of them. Looking closer I recognized another Russian detective. Turning to the master-mason, I saic: 'Do you know this man?' He replied: 'No, but the late strike has made it so hard for me to get workmen, that when this man applied I employed him.' When I said to the man in his own language, 'Leave 
this place immediately, or I will shoot you dead!" he required no further permission, and got away in a hurry."

Had you no other clew to these wicked designs than by such as you described?

"No other was really necessary. One soon learrs the peculiar methods of nations in dealing with their enemies, and Russia does not easily forgive. The unlimited power of the Czar must be incomprehensible to the inhabitants of a country, where freedom of speech, and the liberty of the press, are the inborn rights of every citizen; where no secret fear of unexpected and undeserved captivity or punishment influences every action, every thought, almost every breath one breathes, and every dream one dreams."

Has the banishment of the Jews from Russia been in any way a matter of personal interest to you?

"None, except that I have learned that among them is an old servant of mine, and that he is now living in Wilkesbarre. The immense population of Russia was composed largely of Jews, and their power and influence, although a secret one, was sufficiently felt to interfere with, and sometimes interrupt, the designs of the government. The lower classes, it is well known, served the most immoral purposes in the hope of getting wealth."

In what way specially?

"Many drinking dens of the vilest sort were in the hands and under the control of the Jews, while everywhere they were the acknowledged receivers of stolen goods. Famous as successful horse-thieres, their different depots for the reception of stolen 
horses were long distances apart, but in every hamlet and village through which they passed they were sure of protection and non-betrayal. Faithful to each other, they were at secret enmity to the rest, and their great and ever-increasing numbers made their adverse influence one to be dreaded, in so haughty and arrogant a nation as Russia."

Then you are not surprised at this terrible upheaval in Russia, and the persecution of the Jews?

"Ah, no! It cannot be to me a matter of astonishment that the Jews are finally expelled and forever banished from Russia and Poland."

But there must be some good men among this great army of sufferers?

"Among them are many good and honorable men, and as such they will be recognized here and everywhere. But the edict had to include all or none, and while the means employed to banish them were cruel and severe, Russia can shrug her shoulders and show to the world, in her disdainful attitude, her indifference to the opinion of all other nations."

Well, dear Count, we are not only glad to welcome you to America, and to adopt you as one of her sons, but, even at this late day, congratulate you upon your escape from all those wicked designs, and that you still live to tell about them.

"Ah, my friends, there is no country in all the world like America; and I thank God every day of my life that my steps were directed hither, and that now in my old age I can enjoy the inestimable blessings of perfect liberty of thought, and freedom of action, which she bestows." 


\section{CHAPTER I.}

VETERINARY EDUCATION.

I SEE you have prepared a lecture for us this evening, Count, and intend to tell us what these figures in plaster-of-paris mean.

"They represent the anatomy of a horse. I have modelled them, for the better understanding of breeders, owning valuable animals. One outlines the muscular formation, with all the tendons and ligaments; while the other is a complete skeleton, showing nature's marvellous arrangement of bones, and the working of the intestinal functions."

How very cleverly done they are!

"Well you see that when a horse is ill from accident or disease, his condition is better explained by a reference to the models. For instance, when I was called lately as a witness in regard to the soundness of a horse, I could prove by a drawing submitted to the court the condition of the horse's hoofs, which were separated from the lamina. The judge, comparing the drawing with the model, saw easily where the difficulty lay, and gave a decision in accordance with my statements."

Where did you study, Count?

"I have my diploma from the Maramonte College 
in Warsaw, and, with the title of colonel, was in the Pietro Pavosky stud staff of Alexander II. of Russia for many years."

Veterinary surgery is considered an important science?

"In all countries under military rule it ranks with the highest of the learned professions."

Indeed! you know we rather look down upon a man here, who can find nothing better to do than to doctor animals. One can hardly insult a physician more, than to ask him to set a dog's broken leg or otherwise prescribe for him.

"Yes, but it is very different in Europe. There the veterinary students are taken from the best of the nobility, from the cleverest and best educated sons of gentlemen. In Russia, Germany, Austria, and other countries under military government, horses are not sacrificed, if by any amount of care and attention, they can be saved. A Russian general argues that ignorance is inexcusable, where the illness or wounds of a horse are concerned; and as fine horses are scarcer than common soldiers they are well taken care of."

Then the soldiers are not of so much account as the horses they ride?

"It is even so. If a soldier or groom should lose a valuable horse through any neglect or oversight, he is likely to pay the forfeit with his life!"

Then the course in veterinary science must be a very difficult one?

"It is, indeed, madam. The rules are strict, the examinations very rigid, and it is only after a long 
course of hard study that a student receives his diploma."

And in Europe a diploma is really a necessary equipment?

"Certainly, it is there, as here in classical colleges, the proof and reward of close and serious study. There are seven primary classes which prepare the student for practical work, which is at first disheartening, for with all his book knowledge he seems to have nothing to start with. An animal cannot tell his ailments, or where the pain is, and the doctor must find out for himself. Now, if the student can pass an examination he may be assigned to a place in the imperial studs; but at every advancement on the military staff, he must pass a new examination, until at the end of five years, he becomes a graduate with the title of veterinary surgeon and animal doctor."

Is it possible the course includes five years of hard study?

"No less is sufficient. In nearly all European countries the animal doctor advances through military service, aided by the close and practical observation of and association with his own horses; attending personally to their needs, even to the blacking of their hoofs, albeit his servant may blacken his boots. The course includes all that medical science teaches whether of biped or quadruped, with feathers or without. He must be practical in everything, even to the forging and fitting of his horses' shoes, a most important thing to know."

Are there many such colleges in Europe, and which is considered the best?" 
"The highest veterinary college for cattle is in Switzerland, and that in England ranks next. But in England the college is not under government control, as it is in Russia, Austria, Germany, France, and indeed all European countries under the régime of military law."

Are they not very strict in those countries regarding meats and their healthy condition?

"Indeed, yes, and it is most important everywhere. In these countries there is a veterinary surgeon on every Board of Health to determine the sanitary condition of suspected animals, before they are butchered. In Bavaria every hog is examined by an animal doctor before it can be sold, to avoid trichinosis, and since the horse has been declared good for food the fact proves that veterinary science has made great strides."

Then science has proved that horse-flesh is good to eat?

"It has, emphatically so. Horses were formerly too expensive to buy for post-mortem examinations. Now, if a horse break his leg, and so being useless is killed; if, after examination by a veterinary, he is pronounced healthy, he can be cut up and eaten. The custom has become too common to convey an idea of horror as it once did. In some cities there are restaurants, where horse-flesh is the only meat provided. Then our daily accounts during the siege of Paris, and the high esteem in which horse-meat was there held, have helped also to cure us of this idea."

We might then have saved our shudders, and our sympathy for the horse-devouring community. 
"They could not starve while having sound horseflesh to live on. Three fourths of the support of almost every country is supplied from the animal kingdom, which statement although it may offer a wide field for argument, is not difficult of proof. To cite an exception: in the tropical parts of Africa there is a fly so destructive to animal life that only the goat can exist there. The men and women, perforce, are beasts of burden, and travellers must walk and carry their own luggage. In China, because of the enormous population, only the very rich can keep cattle and horses. Where the population is not so dense the animal is freer, healthier, and tougher, not stronger nor more speedy, for a wild beast can always outrun a domesticated animal. In the Orient all animals that sweat only from the tongue are considered unclean, while those that sweat from the pores, including horse and man, are good for daily food."

Is not that a rather heathenish distinction?

"The Bible speaks of 'Wise men from the East,' and in all that pertains to mankind and animals, the Orientals have strict laws, founded on the closest practical observation, which have become an essential part of their religion."

Then the fact that men sweat from their pores as do horses, makes the excuse in the cannibal's mind, when he regales himself on a particularly fat and toothsome missionary?

"Ah, madam, I fear religion plays a small part in the cannibal's peculiar appetite. He eats his enemies with relish, his neighbors with the blackest hides: 
Has not the missionary with his dainty white skin, a high courage to put his tempting self within reach of their long arms, much as he may wish to convert them to more civilized dishes and ways?"

$\mathrm{He}$ has indeed. But to return, do you find a creditable amount of knowledge among the veterinarians here?

"Until.within a comparatively recent period very few have ever been out of America, unless imported from Europe. They did not possess stables of their own and were mostly interested only as hired physicians-not as owners of valuable horses. The finest racers in this country come from the least pretentious stables, as a stricter, closer personal attention is exercised by the proprietor, and important needs are not left to the grooms." 


\section{CHAPTER II.}

FACILITIES FOR BREEDING IN AMERICA.

WHERE do our best horses come from?

"They are imported principally from England. From English thoroughbreds we get our hunters, runners, trotters, hackneys, post and cart horses, etc. Books have been written upon the subject which tell about selecting good horses for breeding purposes, but they have not yet learned how to get a good horse from poor parents."

But is that possible?

"Certainly it is. They understand the result of certain combinations, but with all the wonderful facilities in America, men have yet to learn how to mate horses, so as to be sure of securing one that will trot in two minutes, all the way to one that will trot in $\mathrm{I}: 50$. They do not understand how to combine the breeds, so that the inbred, so far, is only occasionally good. To mate extremes, such as the Arabian with the Shetland pony, is not to produce good results. In mating, the mechanical proportions of a horse, together with lungs of great volume and capability, are of the highest importance to consider. From endurance you get the greatest speed, but from the speediest horses never endurance. Physiological 
laws in mating should be well understood. So, instead of one phenomenally good, once in a while, it would be the rule to secure always the finest animals. In America there is everything to favor the highest development to which the horse can attain."

What are the special facilities in America?

"First, there is immense wealth and a generous inclination to spend it; second, the great diversity of climate agrees with the horse, if not always with man; and, third, food is never lacking, there being also a great diversity in hay, certain herbs growing among the grass, which are exceedingly nutritious and delicious to the palate of a horse. Then the country is wide, the air is pure and invigorating."

You think horses prefer the country?

"They delight in the open freedom of air and space. If living in confined places, too close to mankind, they will contract similar diseases, and men will also be affected more or less through contagion."

Is it possible that human beings have the same diseases as horses?

"The illnesses of both bear a close resemblance, though producing different phenomena, as in persons. Colic in horses is very alarming and distressing, and extremely dangerous to life, if not taken in time. It is far more severe than in man, and if not speedily cured may make an invalid for life of the animal."

What medicines are used for colic?

"Strong opiates are the surest remedy. Sunstroke is easily managed, if understood, is not at all 
uncommon, being frequently taken for blind staggers, although the symptoms differ somewhat."

What diseases are incurable?

"Physical malformation and glanders. A horse afflicted with glanders should be shot more quickly than you would shoot a mad dog. He should be buried deep with plenty of quicklime to cover him. The disease is so infectious that the flies carry it, and with it infection to human beings as well as to other animals. La grippe bears a close resemblance to glanders though in a much milder form, but if a man takes glanders from a horse there is no cure for him."

Are the symptoms easily recognized?

"The symptoms of other diseases not dangerous, are sometimes similar to, and mistaken for, glanders. Only the other day, I was called in great haste, to see seven valuable horses, condemned to be shot by the attending veterinary. As I could not discover the leading signs of glanders, I examined them carefully, and could assure the owner that they had been unjustly condemned."

He must have been delighted to hear it.

"The expression of relief on his unhappy face, showed that Hope had entered into his heart. One of the horses had already suffered the sentence of death, so in order to be sure he requested me to make a post-mortem examination. I did so, at once, and finding no yellow spot on the liver, heart, kidneys, or other interior organs, I could assure him, that his fears were groundless, and that his horses could be cured." 
And did they all live?

"Ah, yes, madame. Every one of them is now at work and as well as ever."

Only yesterday I read of a man dying from glanders. He tried so hard to cure his beautiful horse, but he caught the disease and both fell victims. Is it possible to mend a broken leg?

"It depends somewhat upon the locality of the break, and the value of the horse. I had a valuable mare hanging in the 'cradle' for four months, having set her leg, put it in splints, and covered it with a plaster-of-paris jacket. When the inevitable stiffness had worn off she trotted as well as ever; but the cure of course required the greatest care, and was attended by very great expense as well as much discomfort, not suffering, to the mare on account of her enforced position."

But it was well worth the trouble, was it not? Other animals are always killed, I understand."

"Not always. A year ago I set the broken leg of a little calf, which has now grown into a fine heifer, and indicates in no way her previous misfortune. A valuable dog should never be shot for a broken leg, when there is a chance to save him. Many a dog's leg I have set and every time have gained a warm, true friend." 


\section{CHAPTER III.}

THE SENSE OF SMELL IN THE HORSE.

Of course, Count, you have read what Madame de Staël says, that "the sense of smell is the noblest of the senses." Is it the keenest sense in the horse?

"While the senses of sight and hearing are preternaturally acute, even more so than in dogs, the sense of smell is exceedingly fine. It answers to the combined senses of touch, taste, and smell in man. If a horse can investigate an object to his satisfaction

- with his nose, he no longer fears it."

Is this true with regard to the steam-engine, that bête noir of the horse?

"He may see and hear a steam engine, and through these senses exhibit fear and anxiety to get away from it. But if once coaxed close and held firmly near it, and made to smell of it, he will never show or feel the same fear again, and aided by sight and hearing can soon be broken to its various manifestations of noise-escaping steam, whistle, and shriek."

Then it is important to take him close enough to the locomotive, to let him smell it in order to break him properly?

"His nose will convince him of its harmlessness, when eyes and ears fail."

How can he conquer his fear of wild beasts, even 
when they are caged or tamed-he surely smells them?

"To his natural enemies, even in bondage-the lion and tiger and other carnivorous animals-he manifests a strong aversion; but if his nose can be rubbed with something from their cages, even the straw in which they lie, he will no longer fear their terrible roar and will pass them by in lofty indifference. Whether the smell of the cage conveys the idea of captivity it is hard to tell, but these are facts easily proved."

Is it not wonderful how horses seem to enjoy the excitement of battle?

"The horse hates blood, but rub it on his nose, as the soldiers sometimes do before going into battle, and he will no longer shun it. It is the unexpected and the unsmelled that so scares even the most amiable animal. In his master whom he loves, he places wonderful and abiding confidence, and appreciates the decision and determination coupled with kindness, that will finally conquer him. When other efforts have failed he will follow his example and will take the plunge into deep water which he has refused, if his master plunge in first and will swim with him."

Ah, yes! I have read many a traveller's tale, how he has been saved from impending death through the simple discretion, instructive wisdom, and more than human endurance of his horse. I am sure you must have many such experiences.

"I will relate to you one, which seems even to me almost incredible. Being wounded in battle, and 
falling from my horse unconscious, the noble creature seized my clothing in his teeth, and lifting me from the ground, carried me to a safe distance. Three times in the course of this removal I recovered consciousness, when he would lay me down again most carefully. Each time I found myself farther away from the scene of battle, and at last began to revive. Some of my regiment had followed us, but brave Omar would allow nobody to approach me, standing guard defiantly over me, until my own servant arrived."

How dearly you must have loved so noble an animal! Where did you find one of such rare intelligence?

"Omar II. was of the pure Nedj breed of Arabia, the rarest and finest in all the world. His father, Omar I., I obtained by stratagem (as well as his mother, Ansha), leaving in his place $\$ 15,000$ in gold, as these horses are never bought or sold. Omar II. had been my especial pet and charge since his birth, and a more perfect animal never lived." 


\section{CHAPTER IV.}

NATURE'S VINAIGRET'TE.

I HAVE often wondered, Count, what the dry gray warts on the inside of each foreleg of the horse and about the size of a silver dollar could be intended for. They are the only spot on all his beautiful body that could be called unsightly, and so I questioned an owner and breeder of fine horses.

"And what did he tell you?"

He said that he had thought the osselets, for so he called them, a sort of safety-valve through which the blood was rid of its impurities. So when one of his horses had "scratches" he peeled off the layers as close as he could, and watched the results. When the "scratches" went away he attributed the cure to what he had done, but admitted that it may have had no influence. He thought also that when the horse rubs his nose against his legs he may be trying to peel off the layers and thus get relief from some little ailment. Is this your theory also, Count?

"Ah, madam, that is a question that has been asked over and over again by men of science, of deep practical learning and observation, without discovering any satisfactory reply. I have made experiments, and have come to a conclusion that is bound to meet with doubt, possibly scorn, from those who 
always doubt and from the ignorant and unthinking. But I am satisfied of the truth of my discovery."

Pray tell me about it, for these osselets seem to be of no possible use.

"Everybody who loves horses and observes their ways, will have noticed that after a long and fatiguing journey, or sustained and tiresome work, the horse will rub his nose, first on the inside of one foreleg and again on the other, tossing his head meanwhile, throwing it about and taking long deep breaths of relief and satisfaction."

Yes, I have very often noticed it.

"I believe that Nature has furnished to our domestic slave the noblest of all God's brute creation, her vinaigrette and restorative. When the weary, overtaxed animal, sweating at every pore, and covered with foam, can reach down and rub with his wet nose, this always dry hard substance, he is instantly refreshed with an odor like that of geranium. Tossing his head with delight, and sniffing perceptibly, he applies again and again his wet nose to this bountiful, secret, and cunningly arranged restorative, and is thus fortified and strengthened sufficiently to resume his journey."

And have you really tested this wonderful theory to your own satisfaction?

"To test my belief I removed from one of my horses these warts in the foreleg over which the skin grew healthily, but the horse never showed the same endurance, and his value was diminished by half. In another case when I experimented, an eruption broke out over the healing wound, and the 
poor animal soon grew so lame and useless that he had to be shot, a sacrifice to science. These two experiments were sufficient, I think, to test the wonderful truth of what I have said. By wetting the fingers and rubbing them on these dry warts the unmistakable odor of geranium thus generated must carry conviction to the most unbelieving."

Is it the same whether in horses of pure or impure breeding and blood?

"The higher the breed and the purer the blood, the more pronounced is the odor; and small osselets indicate fine breeding. The native Arabian in his swift and never-ending journeyings to and fro in the scorching heat of the unprotected desert, with scant food and most limited supplies of water, draws constant stimulant from this, Nature's nosegay; and the weary cavalry horse, on forced marches, lets his head droop lower and lower to catch, perchance, one more whiff of the grateful and sustaining odor."

Your argument would be a powerful one against the bearing-rein, but are other animals similarly provided?

"It is a remarkable fact in natural history that every race, whether of man or beast, and everything that has life, which grows in or from the ground, is distinguished by its own peculiar odor. This odor is agreeable or not, according to its delicacy or the strength to which it is developed."

And has it a similar purpose?

"In many cases it is bestowed by Nature's wonderful forethought, as a means of offense or defense, and many animals carry with them a well-supplied vinai. 
grette which, in times of exhaustion, they turn to and inhale exceeding refreshment therefrom. In some the odor is perceptible to themselves only, while in others it is such a powerful means of defense as to make the pursuing victim wish he had never been born, which floods cannot drown nor fires quench, if any part escape, and only six feet of earth can extinguish."

I know of one, are there others?

"Notably among these is the musk antelope, which sends forth such a powerful odor of musk that even at the distance of one hundred yards he can smother his enemy to death."

Is musk never made from plants?

"Musk is entirely an animal perfume, and is contained in a bag situated near the perineum, which, by muscular contraction or expansion, the animal can control at will. Experienced hunters know that when shooting, even at longest rifle range, a musk antelope or a mountain goat, if the wind be blowing toward them from the animal, they must immediately drop and bury their faces in the ground, or the last effort of the expiring animal will carry to them also certain death."

What accounts for the very perceptible odor of musk in some churches in Europe?

"In Constantinople the Mohammedan Mosque of Sofia is pervaded always by a strong smell of musk. In order to supply this perfume, which was freely mixed with the mortar and cement which bound together the stones, thousands upon thousands of the musk antelopes were slaughtered. Thus, while one 
stone is left upon another of this ancient and interesting building, the odor of musk must remain to refresh or to annoy its visitors, according as the sense is affected."

Has musk not some medicinal qualities?

"Taken internally after being dissolved in water, the substance of this little bag is said to be an excellent specific for pulmonary diseases. It is, too, a well-known fact that the negroes of the South value highly_and are not deterred by the necessarily close and nauseous proximity to obtain it-the substance of the pole-cat as a sure cure for rheumatism as well as for coughs and colds."

Then the odor of musk belongs to many animals?

"Musk is probably the most common of animal perfume, or at least the one which we are best able to recognize. The muskrat, inhabiting our own ponds and ditches, is greatly in demand by the compounder of perfumes, and it is a species of jollification to hunt them, which dogs and negroes enter into with excited zest. In all thoroughbred cattle there is a small cavity in the head, immediately between, and at the root of, the horns. By rubbing the fingers in this cavity a distinct odor of musk will be perceptible in them."

How in this position can it refresh the animal?

"That is Nature's secret, betrayed only to the owner of it."

Have I not heard that beavers betray themselves by a peculiar odor?

"Yes, beavers emit an odor, well known to hunters of them, in which it seems that Nature cruelly favors 
their enemies. The poor little industrious creatures, so valuable for their pretty fur, fancying themselves secure in their hidden dams, reveal by this freak of Nature their hiding-places, and thus become easy victims to covetous man."

Are not foxes an easier prey for the same reason?

"When the hunted fox is sore bested and the hounds are gaining upon him steadily and surely, he will be seen suddenly to turn himself round and round, with bewildering rapidity, and with his head and tail in close proximity. After several of these revolutions, he makes a sudden spurt and soon gains a great advantage of distance between himself and his pursuers; and if luck be with him he may escape. Many a huntsman through a long life has chased the fox with enthusiastic ardor, who would be surprised to know, that in the very tip of his tail or brush is a little bunch of hairs, from twenty-five to thirty in number, which gives forth to the despairing and almost vanquished beast, the refreshing and stimulating odor of violets."

How very wonderful!

"With this choice vinaigrette of Nature's furnishing the hunted creature is sustained."

Then this simple fact may explain why the hunters return in such unsatisfied humor?

"Ah, I have laughed to hear them making the air blue, with vengeful threats against the sly old fellow never yet run to earth, and who again and again has outwitted them."

But does not the fact help the hounds also?

"Doubtless the hounds with their keen scent, fol- 
low with delight this delicious perfume, and find it an added incentive to their murderous designs. Deprive a fox of his brush and let him go, and the subsequent sport of catching him will be of very short duration; for his run will soon come to an end, and the whole pack of huntsmen and hounds will be in at the death."

Madame de Staël's idea of the sense of smell may have been founded on some such knowledge, and she may have had a long nose as well as a large foot.

"How so, madam?"

You have heard of Talleyrand's retort at the masked ball when she challenged him for recognition: "C'est bien facile de reconnaitre la statue par le pied de Staël." *

"Ah, I remember, but it was a cruel thrust of Talleyrand's."

* It is very easy to recognize the statue by the (pedestal) font of stuel 


\section{CHAPTER V.}

ARABIA.

Your visits to Arabia must have been very interesting, Count! Have you been there often?

"Ah, yes, madam, many times. I have lived among the Arabs in their tents for months at a time, travelling with them in their journeyings from place to place; penetrating into the very depths of the desert, and longing with them for the sight of an oasis after the intense heat of the day."

Then you speak their language?

"That goes without saying, and many of their dialects also, which are important to know."

Had you any special object beyond the love of travel, to induce you to spend so much time with them, and were they always friendly?

"To me they were always friendly, for the reason that some of their remote ancestors were mine also, and with them nothing is so strong as the ties of blood. Their pride of race is one of their strongest characteristics, since they can trace back their ancestry for thousands of years. For aliens and strangers they have a certain contemptuous pity, as not belonging to them, as well as much distrust and suspicion."

I have heard the old adage, "In the desert no one meets a friend." 
"Yes, it is one they verify daily, unless the rites of hospitality have already been offered, and bread has been broken with the stranger in the 'tents of Shem.' But they have certain unmistakable signs to show that their entertainment is at an end, and no hesitation then in declaring themselves at enmity."

Are their manners agreeable?

"The sheiks have a grave and haughty dignity in their bearing, and polished manners, so affable that they can quickly secure the attachment of neighboring tribes. Gifted with a courage never yielding and never dying, they are also born traders, and soon acquire great influence in their surroundings."

You must have made opportunities to learn everything possible about their famous horses?

"My object in visiting the Arabs was always to purchase horses, and while I was prepared for trickery and even treachery in their dealings, I succeeded, even if stratagem were the means. They knew I was not to be deceived easily, and the remote ties of consanguinity had its influence."

How do they deal with strangers?

"If a man comes armed with wealth and might, desiring to purchase a favorite horse, the Arab will plunge into the desert, inaccessible except to the native, and there hide himself and his horse until the danger of losing him is past. But if the intending purchaser brings only money, he had better have stayed at home, for the Arab will first kill and then plunder him. They are notorious highwaymen and the laws of their country shield, rather than punish such misdoings." 
It is said that Arabian horses have deteriorated, Count. Can it be true?

"Indeed, no. It is impossible for the true Arab horse to deteriorate so long as the Arab tribes follow the same laws, and so jealously guard their rare breeds from loss by sale or theft."

But we are said to have many Arabian horses here in Europe and South America?

"They have a race of horses called the Levantine, which they offer in exchange for money and merchandise. These horses have excellent points, are showy, handsome, well-trained, and in every way desirable, but they no more compare with the true Arab breeds than a clumsy cart-horse to the swift runner."

Are there many distinct breeds?

"There are but five, and every one entirely different and with distinctive marks. Those most highly prized, most rare and valuable are the Nedj and Osman. The other three, the Abdalla, Mohammed, and Dakir, although of blood as pure and as impossible to obtain by purchase, have not the same match less beauty."

But were not the horses presented to General Grant thoroughbred Arabs?

"There are many conflicting opinions regarding - these horses, and their claim to being the thoroughbred Arabs of the desert. It was thought they must be so because they were presented by the Sultan, but if you asked an Arab he would tell you the Sultan never owned one of these rare breeds, and never had one in his stables." 
Have you ever seen Leopard, or Linden Tree, whose arrival in this country made such a sensation?

"No, madam, and never having seen them I cannot express any opinion. Among horsemen in Europe who study the different breeds, it is believed they belonged to the Levantine family, being showy, stylish, strong, and with many fine points."

Have you any other reason for believing so?

"As I have said before, these rare breeds which I have mentioned, are considered so precious that every precaution is taken, not only by the owners, but by the whole tribe, to prevent their loss, by sale or intrigue. The Arabs, with all their peculiar creeds of hospitality, have never arrived at that state of civilization which could induce them to give away such treasures. If an owner should be tempted by an enormous price to part with a mare or stallion - there are no geldings - he would be put to death by his tribe, while the man who had the temerity to seek such a purchase, must do so at the risk of his life."

They must take peculiar measures to prevent their loss.

"Every horse lives inside his owner's tent and is the pet and delight of the women and children, and quite as much a part of the family. Their intelligence is almost human, as they answer in obedience to every word, and are so trained as to help their owners in defeating any attempt to carry them off."

The endurance of the Arab horse is very remarkable, I have heard, Count.

"It is almost inconceivable. From the days when Noah's ark settled on Mount Aararat and his sons 


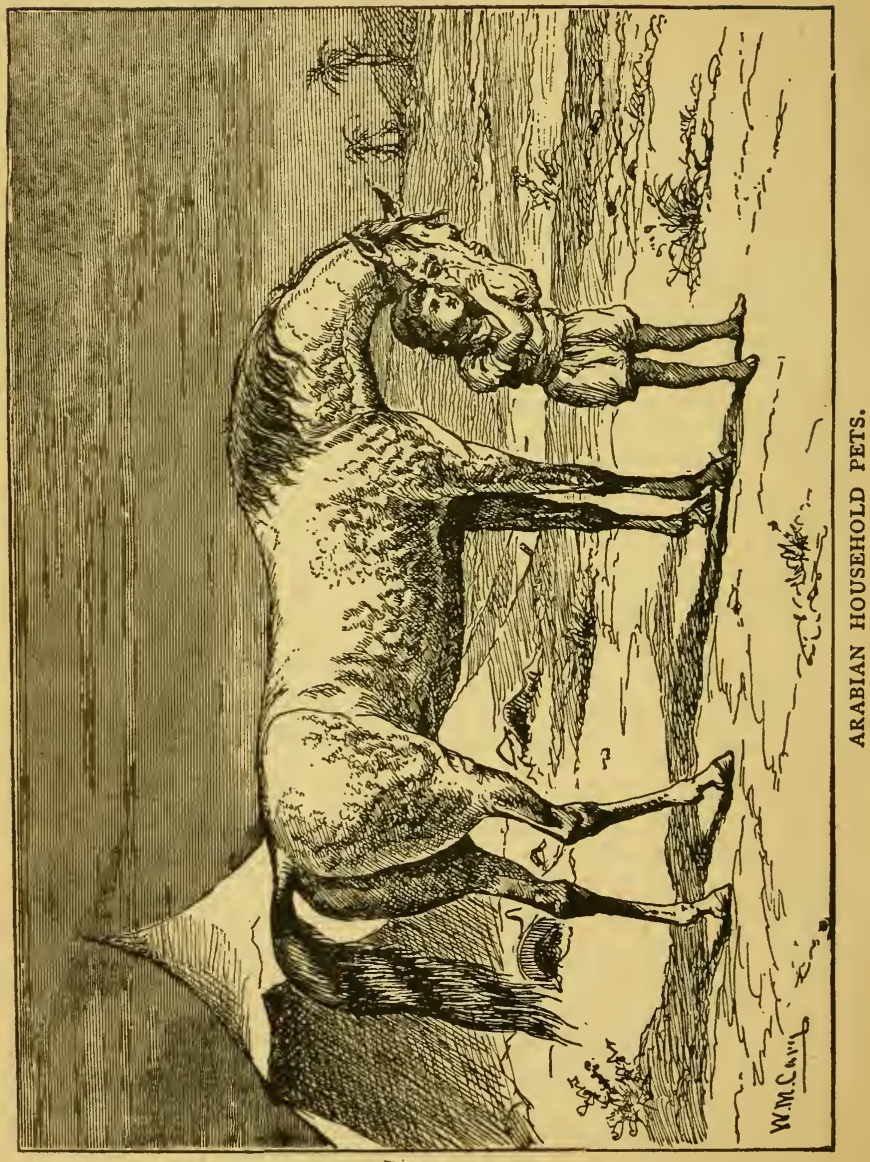


descended to the plains of Shinar, or from those of Nimrod, his great.grandson, the 'mighty hunter,' down to the present day, the Arab has been bred to endure long days of continuous toil, semi-starvation, and thirst." 


\section{CHAPTER VI.}

FAMOUS ARABIAN HORSES.

I HAVE heard the saying, "Never let an animal lose its sucking flesh."

"Yes, it is an axiom with English breeders. The Arab foal, on the contrary, while it may enjoy for the first few months of its young life, the pastures and watered plains of 'Araby the blest, endures great privations. Its tender little feet must trot along after its mother on many a forced march, subsisting on the scantiest of fare, and esteeming a little camel's milk the greatest of luxuries. These are hardships for the baby Arab, not lightened by the fierce and perpendicular rays of the sun on his head and spine, and the blistering sands under his feet."

One cannot wonder that his growth is somewhat stunted, for Arabs are small, are they not?

"Yes, they are small; but what the Arab lacks in grandeur of physique, as seen in the English thoroughbred, the Percheron, or the enormous coach horses now so fashionable, he makes up in his perfect proportion, his proud and dainty and graceful mien and bearing, his never-failing courage, his iron constitution, his delightful temper and disposition, his entire soundness, and his extraordinary 
ability to travel great distances with untiring speed."

The last quality is a necessary one, when you are running away with somebody else's property, eh, Count?

"Ah, I see you refer to Omar I. He was famous, and now belongs to the Empress of Austria, the finest horsewoman in Europe. For three days and nights he travelled over the hot and barren plains of the Arabian desert with but two quarts of barley for food, and an occasional tuft of the Sahara clover. Only twice was there water found for him to drink. Fleet as a bird he ran, seemingly unconscious of his burden, and arrived at the wall before Cairo, apparently as fresh as when he started. The two Slughi, enormous greyhounds called antelope catchers, which were a part of Omar's outfit, always travelling with him, were lagging many rods behind, footsore and utterly bested. But Omar neighed cheerfully, encouraging them to approach, and promising to them, rest and refreshment in his sympathetic whinnies."

Oh, pray describe him. He must have been wonderful to look at!

"His skin was black, and shone through a fine glossy coat of silver-gray hair; his mane full and long, and his tail, which swept the ground, were pink. About fifteen hands high, in form the most beautiful that can be imagined in any four-footed animal, he was fleet as the wind, graceful as the antelope, trained to every agile movement, and with an endurance inconceivable. In disposition faultless, 
kind, gentle, caressing, and obedient, he had never known whip or spur, or even a harsh word, giving always the best he knew."

Does he still live?

"He was alive when last I heard, having carried the Empress of Austria during her journeyings through Ireland. $\mathrm{He}$ is now forty years old, and still in his prime, as the Arab horses are as longlived as a man."

Do they make good war-horses?

"In battle, their extraordinary evolutions remind one of the gyratory movements of the swallow when it flies. They turn and wheel with such rapidity, that it is almost impossible to get a shot at them, and if they run, nothing can catch them, their wonderful wisdom and cunning leading them and their riders out of difficulties the most serious."

Where are they found?

"In Mecca, Medina, Palestine, and the Persian Gulf are found the Nedj and Osman. They have the Abdalla race in the Atlas Mountains, as well as between Afghanistan and the Persian Mountains, where live also the Dakir and Mohammed breeds. These horses descend as heirlooms from father to son, and no possession is so precious as these exquisite animals."

They also can prove a long ancestry?

"Their pedigree is carefully preserved with that of the family's own, and their names descend as do those of the generations of kings. Sometimes many or all the members of a tribe will be each a part sharer in a horse, and this horse is left by will to a 
successor. One cannot sell his share without permission from the rest, be he ever so much in need; and it must be a most unusual circumstance which could gain such permission."

Is there not some strange legend concerning Arabian horses, Count?

"Yes, and it is said to be a true one. The legend is this: During the reign of Mohammed he sent his grand vizier with his army in the hope of conquering China. For five years they travelled over mountain and valley, through forest and desert, climbing rocky precipices to descend on the other side into the rivers and streams. Unparalleled hardships befell them on their long journey thither and were not lightened on their return, inasmuch as every horse died on the road except five beautiful mares. From these and the Dzigguetai (pronounced Gigati) are descended the five rare breeds so closely guarded by the Arab tribes."

What are the Dzigguetai?

"They are the wild Arabian stallions of the desert, outmatching and outwitting the wary and cunning Arab in his various devices to approach them, never letting them get nearer than half a mile. After exhausting every other artifice, the Arabs have lain concealed in the desert by being buried in the sand for days and nights. in their fruitless efforts to secure them. But these untamed and untamable creatures, with their intelligent instinct, ever scented danger from afar, and kept their half-mile distance between themselves and their would-be captors. Their strength and endurance are greater than that 
of the Mohari, the desert camel, and they. are far more fleet. These powerful runners brook no rider, no whip, spur, or bridle, nor have they ever been captured or broken by man."

How, then, could they be made useful?

"In this dilemma it occurred to the far-seeing Arabian, that this race could at least be perpetuated and improved, by arranging some equine marriages. Picketing the five beautiful mares near their hunting-grounds, they were offered as brides to the Dzigguetai and accepted. The result gave everything most valued in the horse, as well as his matchless beauty:

Do they differ greatly in color and appearance?

"The Nedj and Osman have always a black skin under their coat, whether it be white or black. The Osman is usually the color of a golden chestnut or blood cherry, with dark mane and tail, while these equipments in the Nedj are pink or rose-colored. The Abdallah are a warm gray, inclining to black, with dark mane and tail-the Arabian term to express their color, translated, meaning green. The Mahomet is light brown or café au lait in color, sometimes dark enough to be called bay. The Dakir is a dark shining brown, and the manes and tails of all are long, fine, and full, but not heavy."

Do they wear shoes? A great traveller, one who had lived in South America, and there owned Arabian horses, told me they were never shod in that country.

"As their hoofs are hard as iron they need no shoes, and die at an advanced age without having ever worn them." 
What are the distinguishing marks by which one can tell an Arabian?

"The pure bred Arab is sma1l, with such fineness - of skin that through it the veins can be clearly traced. The head is small and lean, with bold open nostrils, thin as cardboard. Very broad between the eyes, which are large and soft, and look at you with an expression of human intelligence. Ears small and erect, fine and thin as a kid glove. Mane full and long, not heavy. Tail almost touching the earth when standing, but lifted out when in motion, and waving to and fro like an ostrich plume. Thighs, fore and hind, immense. The frontal bone below the knees very slender and round like a finger when viewed from the front; from the side it appears wide and muscular. Hoofs very sma1l, hard, and polished. Height from fourteen to fifteen hands. Gait an even stretching gallop, which never trembles and never tires, sure-footed as a mule, and tender-tempered as a baby."

Your description is enchanting, but only convinces me that I have never seen a thoroughbred Arab. Is there no more to be told of the Dzigguetai, Count? "I had a convincing experience that they can travel from two to three hundred miles, in twe consecutive hours, in order to drink from a certain clear cold spring in one of the oasis, and to feed on the dainty nourishing grass there."

O Count, that seems incredible!

"I realize that the statement sounds most exaggerated, and I myself could hardly believe that flesh and blood could equal the locomotive's speed. I have 
lain concealed with the Arabs behind the rocks and buried up to my neck in sand, hoping they might thus approach us more nearly. Stationed at a certain oasis in the desert, over roo miles distant, were men to note the time of their arrival there. How they flew past us in the half-mile distance! It was like watching an express train disappearing from view, while the thunder of their many hoofs scarce lasted longer than the roar of a passing train! They had method in their going, and a leader whom they followed. Their bellies hugged the ground, as their slender legs carried them on with long strides and an easy motion, in which there was no haste, but immense untiring speed, and infinite lightness and grace. For twelve hours we waited and watched for their return, and were finally rewarded by hearing approach the sound of their many hoofs, and could see them fly past us with undiminished speed, on their return. My men stationed so far off had noted there, carefully, the time of their arrival. By comparing it with that of their return, which I witnessed, I make no exaggeration in my statement. To be still more sure I tested these facts many times." 


\section{CHAPTER VII.}

PEDIGREE OF ARABIAN HORSES.

HAve I not heard, Count, that the true-bred Arab has concealed marks by which to be identified?

"On every Arab, born and reared in the desert and belonging to the families mentioned, are to be seen certain fine marks, intelligible only to the initiated. When the colt is young a very fine hot iron, like a needle, is made to write certain marks and lines on the forelegs, to the right and left of the

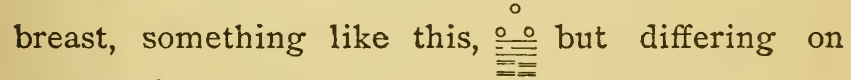
either side."

Is it not a painful operation?

"No, for it is done too quickly to be very painful. Several of these needles are heated at the same time, in burning camel's manure. One is taken up, a stroke or two made with it, and replaced in the heated mass. Then another is used and so on, until the delicate, but perceptible branding is finished. The skin heals rapidly, and the young colt carries the long list of his ancestors about with him, for the rest of his natural life."

But does not the hair grow over and cover these slight marks?

"The hair never grows long enough to cover them 
entirely: hence, by the uninitiated, and even by travellers and horsemen who should know better, they have been called 'blemishes,' and 'disfiguring - marks.' An Arab's first glance at a horse is for these important signs. The more marks the horse has the longer his pedigree, and the more he is to be coveted. The blood has been kept pure for so many centuries, that any stain in it derived from possible crossbreeding, would be considered ineradicable forever. I will show you the picture of Gherka, an exquisite Arab, whom I owned many years ago, and who was shot under me in battle."

But she has marks on her flanks also!

"Certainly! That on the hind flank represents her family, which was Nedj. The one on the shoulder signifies the province, Oran, where she was born, and the name of the tribe 'Kehilan' is that to which she belonged."

She wouldn't have found it easy to lose herself, thus adorned with her family history; but I imagine few foreign eyes have ever beheld an Arabian of such absolutely pure blood?

"Very few travelers who have penetrated into the desert for the purpose, have ever been rewarded by the sight of these, as they are hidden away from strangers; and other breeds of shorter pedigree, and far less value, are brought forward to show their paces, and perchance bring an incredible price to their astute owners!"

Are these marks not very hard to read?

"To the scholar learned in cabalistic lore these hieroglyphics are easily read, for beginning with the 


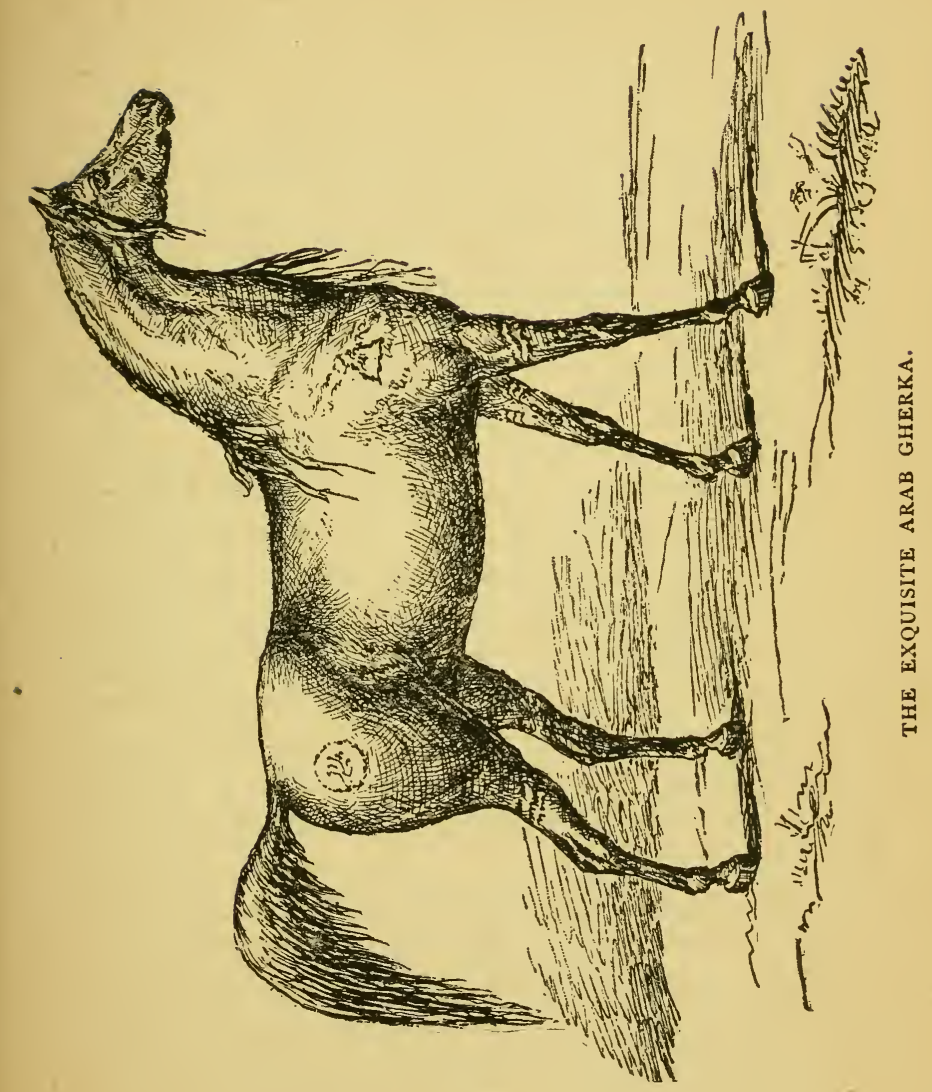


father and mother they indicate the ancestors for many generations back. Should any one buy a horse so marked in America or elsewhere, he will behold a thoroughbred Arab, but without these marks he is not one."

Why are they marked on both legs?

"The signs on the left foreleg indicate the feminine side of descent, the mother, grandmother, greatgrandmother, etc. On the right, the masculine side, the father, grandfather, great-grandfather, etc. An Arab regards the father of a family of very little account, compared to the mother, whether of man or horse."

Is not that contrary to most precedent?

"As a plurality of wives is an essential element in the domestic economy of the Arab tribes, the question of a man's title to distinction, and indeed, almost his identity, must be established by the fact of who is his mother. She belongs to the man who has bought her of her father, as do his other wives; and when she is established in his household, he sets his eunuch to watch her, that no doubt of her virtue may distract his thoughts, or fill his mind with uneasy jealousies."

Then each of his numerous offspring is the proverbial "wise child" in his day and generation?

"Most emphatically so, but to offset the duties of the watchful eunuch, to the mother and wife is shown the highest respect. A man or child may not sit in the presence of his mother without her gracious permission, and to her wisdom and judgment all important questions are submitted. The Arabs 
hold this same peculiar tenet with regard to their horses. Nothing will induce them to part with a mare of any rare breed, and because of their sex they are more highly esteemed and more favored. So in speaking of a man or stallion the question is always, not who is his father, but who is his mother?"

Have the horses in Russia any special value or characteristics?

"The native Turcoman horses are closely allied with the Arabian. They are exceedingly tough, wild, and difficult to tame and teach. So obstinate are they and so wicked that given a good chance they will kill their rider or keeper, and failing this, will persistently refuse to eat and thus starve to death, rather than obey."

Is it possible to break them?

"Ah, yes! Once broken, however, no breed of horses is more reliable or intelligent, or so susceptible to the highest training. 'To the newly-enlisted soldier is given the well-trained horse, which in time trains and teaches the soldier, answering to the word of command in the drill, and going through its intricate evolutions with automatic precision, without the aid of spur, whip, or even bridle. In this way the new soldier is taught."

And what about the new horses?

"Ah, madam, it is another matter when new horses come to be trained in military tactics. Then the old soldier's experience is required, and it is to him that the new horse is given to be broken to martial ways and sounds."

When do ordinary horses reach their prime? 
"Divide a man's age by three and you will understand his comparative relation to the horse, in point of attainment."

Then a horse comes of age, so to speak, when he is seven years oid, as a man does when he is twenty-one?

"Certainly, and when he is five he compares to the lad of fifteen, having had such judicious training as befits his youth. When he is three, he knows as much as the boy of nine, and only so much should be expected of him. In the proud owner's haste to show off and develop the fine points of his young horse, he overlooks the fact that his strength is being tried too early, while his bones are yet too soft for hard work."

Should not young horses spend the first two or three years of their lives in the open field?

"Any other idea is a most mistaken one. They should live in the open air until their dentition is completẹ, so as to draw from the nourishing grass and herbs such tonic as their growing systems need, as well as to develop the full and natural play of their limbs."

Is it not also a great mistake to test the speed of a young horse too soon?

"Because a young horse can run very fast for a short distance, it does not follow he must be immediately trained to run long distances in a specified time, without suffering from it. It is to this mistake that so many fast and promising horses owe their short lives or crippled condition."

Therefore, Count, you would say "Make haste 
slowly" should be the motto of him who sees a rare promise in his pretty, playful, and petted young colt? "Unless he wants to see him condemned to earn his living on the monotonous track of the street car, or pulling about timid women and children in remote country districts, when he might have become a famous racer, surrounded by admirers and enjoying every care and attention his great money value could demand." 


\section{CHAPTER VIII.}

\section{IT IS THE BLOOD THAT TELLS.}

THE primacy of the Arabian horse has never been doubted, has it, Count, even by the most sceptical?

"Their origin is historical from the time of Noah. Notwithstanding all the difficulties attending their purchase they have still entered Europe and other countries as war-trophies-in a very few instances as gifts-and again many have been stolen. Few have been exchanged for money or merchandise, but all countries need the infusion of their blood to fortify and strengthen the best qualities."

What nations have been specially successful in obtaining them?

"The national horses of Austria, Hungary, France, and Italy owe their foundation blood to the Arab. The famous Russian Orloffs came from the fiery desert. To go far back, the Roman racers at Ebor were Arabs. The only horses that survived the first year of the Crusades were Spanish Barbs brought by Raymond of Toulouse and his followers."

What is a Barb?

"The Barb is an Arab, but an Arab is not necessarily a Barb. In the early creation of the English thoroughbred it was discovered that the blood of the 'Eastern Horse' produced speed with endurance as 
well as beauty, which no other type of horse had done. These so-called 'Eastern horses' were named from the countries whence they came, as the Arab, the Barb, the Turk, and the Spanish jennet, but all were included under the head of 'Eastern horses." ",

Of course, Count, you remember the legend, that when the Saracens, were driven out of Palestine by the Crusaders they crossed into the Soudan. Here they met the bold, brave, ever-unconquered tribes of the desert. It is from the Saracens that the sheiks, mounted on the "air-drinkers"- those who drink the air in lieu of water-are supposed to have taken by force the wonderful armor, made of finest links of steel, in which they subsequently rode, and were so invincible.

"I have not forgotten it. But it was also during the Crusades that Cour de Lion rode an Arab of Cypriot breed, 'a magnificent bay,' taken by stratagem from the stable of Isaac the Great, Emperor of Cyprus. Edward of England rode an Andalusian Barb, 'Gray Lyard,' which carried him 'ever charging forward,' in Palestine. That stalwart warrior the 'Cid,' owned a famous stallion, 'Bavicca,' also an Andalusian Barb, and rode, besides, a noted white Arab presented to him by the Sultan of Persia. By weighing the armor of this trio of warriors, now in the Tower of London, the fact is proved that these small Arabs carried 4 cwt. each."

Yes, "it is the blood which tells when the strain comes." Only lately I have been interested in reading that when Sir Gerald Graham was sent at the 
head of six thousand men to chastise Osman Digma, the Egyptian, he did it effectually, but it was the reckless charges of the Arabs, horse and man, which helped to win the day, and to insure Osman's crushing defeat. Then, too, General Gordon, so greatly lamented, showed that the Egyptians could not be made to face the Arabs; as two thousand of them, armed with Remingtons, were put to ignominious flight by only sixty fierce horsemen of the desert, mounted on the famous Nedj racers, "swift as the wind and tireless as the wolf.

"The English found the little Arabs most useful in Egypt, too, for they alone could stand the work and the long marches without water, and with scanty food, and carrying immense weights."

It is in such emergencies that they show their perfection of physical strength, I have no doubt. They are very delightful to ride, are they not?

"Any one accustomed to riding a pure bred Arabian will never ride any other, for there is all the difference between the ordinary English hackney and the Arab, that there is betwen a cart without springs and a rocking-chair."

Do they not make fine hunters?

"In hunting they surpass every other breed; for they go well to hounds, are natural jumpers, bold fencers, requiring neither whip nor spur. Then they have good tempers, good mouths, easy paces, are fast walkers, trotters, or runners, have undoubted soundness of wind and limb, and can travel scores of miles without fatigue." 


\section{CHAPTER IX.}

TYPES OF ARABIAN HORSES.

The type of Arabian horses is very marked, is it not, Count?

"Ah, madam, so pure and distinct of race is the Arab, and so great his power of heredity, that however radical the cross-cut, the mint mark of the desert stili remains. For instance, one proof of his unsullied descent for centuries, is the characteristic spring of the tail from the crupper, and his proud way of carrying it as he moves it to and fro."

Do not Arabs increase in size after leaving the desert?

"The progeny of Arabs once imported for breeding purposes show at once in their increased size, without any sacrifice of power and just symmetry, the advantages of generous living, of a better climate, of petted care, and of a wise indulgence in training."

How many generations before they equal our horses in size?

"In the course of three generations English or American bred Arabs will not lack size. While, as I have said, very few Arabs of the bluest blood ever leave Arabia; yet English pounds, and even the American dollar, backed by the right influence, have 
proved that sometimes gold wins despite the Sultan and the wily horse-copers of the desert."

Because of their scarcity any prejudice against them must be founded on ignorance?

"Ah yes, ignorance is a quality which 'knows it all,' and to proclaim that they have deteriorated is due to the same cause. The pedigree which boasts an ancestry of great deeds and lengthy traditions, is as jealously guarded by the haughty sheiks now as in former days."

But they are brought out once in a while, although the Sultan, considering he doesn't own any, has forbidden the export of the "true air-drinker?"

"It has been always as much the result of good luck, as good management when a purchase has been negotiated. In the times of Abd-el-Kadir fine stallions even were scarce in the Sahara, while to secure an Arab mare was to employ stratagem, which would be considered unworthy in any other trade than horse-dealing."

But aside from the many fine points you have mentioned, why are they so coveted and valuable?

"Because the Arab horse is the primitive blood cause, and has successfully withstood the tests of in-breeding for many centuries. Experience for many decades has so fully justified the production of the Anglo-Arabian thoroughbred, that to reproduce it new blood must be infused, for which new importations of the Arab are necessary."

Is the name Anglo-Arab arbitrary?

"The English discovered, some two centuries ago, that with their native horses, together with the 
blood of the 'Eastern horses,' they were creating several distinct types. Among these was the racehorse which soon became the favorite type, and received the most attention. In due time this creation was called the Anglo-Arab, the word Arab indicating the blood-cause. For many years this Anglo-Arab was exported to the Continent, as the English thoroughbred, for to England was due this new creation. Count Orloff created the famous Russian national horse in the same way, by using Arab stallions to Anglo-Arab and Flemish mares. So France, to create her coach-horse, uses the blood of the Arab and calls it the 'Franco-Arab."

Is not the modern racer considered perfect by most breeders?

"He does not show the fine points and attributes Cormerly seen in horses of an older date and transmitted to them by their Arabian ancestry. The English thoroughbred has failed to hand down to his descendants the primal characteristics of the pure Arabian."

Why has he so failed?

"Because he is not really of unadulterated race. History proves that the race-horses of England are neither of Arabian blood nor yet entirely of Eastern extraction, and cannot, therefore, be entirely thoroughbred."

Do horses inherit particular qualities?

"Just as in man. Many a horse proves his ancestry by what he has inherited. In studying the pedigrees of modern race-horses, one finds that each individual inherits the flaws, which are shown to have existed 
in his ancestor, and often, alas, a multiplication of them. This is the case with the most carefully bred. What, then, can be said of those of much mixed pedigrees, where strains are numerous and derived through inferior animals?"

And do imperfections continue to descend?

"Inferior horses used in the stud most certainly hand down the stain immediately derived from their dam, in addition to former ones. In these later days every consideration has been sacrificed to the development of speed alone, all the science and sound prin. ciples of breeding which our ancestors established being very greatly disregarded. Since the days of King James the First the racer has been the product of careful selection for racing purposes only.'

Have the English always been celebrated for their horses?

"It was immediately after the introduction of Eastern blood, not before, and within the last two hundred years, that the English reputation for own. ing and breeding fine horses began, and it was not until 1808 that the first volume of the stud-book, in which every thoroughbred horse was registered, was issued. If one should look back to the days of Queen Anne and trace the pedigrees given of some horses in her days, it will be seen that nothing but Eastern blood can be found. No better Arabians have ever appeared in England than the black and bay stallions presented by Imaun Seyeed of Muscat to his majesty, William the Fourth. These horses came from the purest strain of the desert, the Nedj. It is, however, be lieved they were never used as sires with thorough. 
bred mares, or even with an Arabian mare sent with them."

What a royal present! But was not this neglected opportunity much to be deplored?

"It was a national mistake, for the three famous English racers, Herod, Eclipse, and Matchem, from whom all modern horses are descended, were only half-bred; got by half-bred sires from half-bred dams, which proves only too conclusively that the English racer is not the 'true son of Arabia Deserta.' Subsequently the arrival in England of Betty Leedes and Darley Arabian, the sire and dam of Flying Childers, caused such a furore that the nobility and landed gentry vied with each other for their possession, and for years after the Yorkshire horses were invincible." 


\section{CHAPTER X.}

ARABIAN HORSES IN ENGLAND.

Owing to the great difficulties of purchase and importation of Arab horses, I imagine that only a few breeders can afford to be enthusiastic on the subject, even in England.

"In England the Prince, or rather the Princess, of IVales heads the list. It is the custom of the Sultan of Turkey to send presents of so-called Arab horses, to distinguished crowned heads in Europe. A tremendous sensation was caused in Turkey and the East by the present of the famous stallion Kouch to the Princess of Wales. The Pasha who was sent over in charge of the horse said on his arrival in England that he had taken many beautiful horses as presents to various crowned heads, but one of Kouch's breed, never before. It was believed the Sultan would as soon have thought of parting with his sultanate as with an Arab horse of this breed, and it was doubtful if he could ever get another like him. It was so unusual a gift that it was confidently asserted that the Sultan would never again be allowed to part with anything so rare and valuable."

Had the Sultan any special reason for presenting Kouch to the Princess? 
"The simple reason of it was the susceptibility of the Sultan to female beauty. He was so captivated by the Princess of Wales, when in England, that on hearing of her great passion for horses, and her great ambition to possess a beautiful Arab, that he determined, on his return to Turkey, to send her the choicest animal in his stable. Of course you must understand that the Sultan had no opportunity at

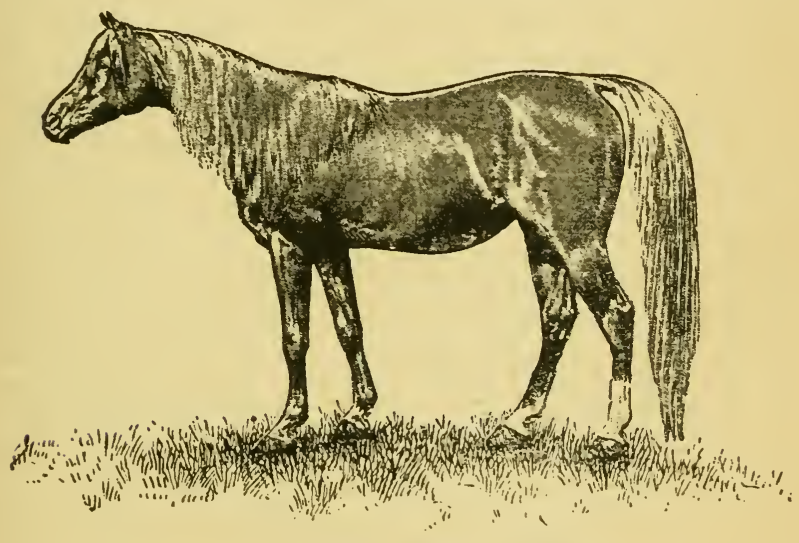

THE ARABIAN MARE, NAOMI.

home, of conversing with any other women than those of his own harem. And so it was that Kouch, the most beautiful horse ever seen in England, the only pure 'air-drinker' in the Sultan's stables, for which he paid ten thousand guineas, entered England."

Is he still living?

"Alas, no; and the only pure-bred son he had, Gomussa-whose dam was Naomi, the only Arabian 
mare now in the United States-was subsequently exported to Chili. Kouch and Kismet were admitted by the Cognoscenti, to be the horses of this century, and now both are gone. Kismet died two hours after landing in New York, having been eighteen days at sea, and dying, no doubt, of pericarditis."

Yes, I heard with great regret of his death, which was a severe loss to two continents. His owner, the Rev. F. F. Vidal, of Needham Market, Suffolk, England, yielded him up after the most earnest persuasions, as a loan to the Americo-Arab Company on Long Island for two years, in order that new blood might be infused into the coming races of horses in America. Mr. Vidal himself wrote me that he was actuated by a hearty sympathy, in the efforts of Mr. Randolph Huntington and his company, to found a family of Arab horses; and that Kismet was a treasure of such inestimable value that he could never forgive himself for letting him go to his death.

"Did Kismet leave no successors?"

Mr. Vidal owns a very handsome pure-bred son of Kismet, "who," he writes, "bids fair to outrival his father in beauty, although no horse can ever do so in other qualities." His little stud of Arabs is said to be the best in England?

Who are the other owners of Arab studs in England? "The Hon. Miss Etheldred Dillon, who has spent year after year in India, Algiers, Turkey, and Egypt, going as far into Arabia as she dared, to secure the precious sons of the desert for her stud, is also an enthusiast. Although approaching three score years, she is still a devotee of the saddle, and owns 
and breeds fine Arabians. Mr. Wilfred Blunt and his wife, Lady Anne, granddaughter of Lord Byron, make up the trio of pioneers, so to speak, in the cause of securing Arabs for the improvement of their studs in England. Officers of the army who have had the advantages of travel and service in Egypt, India, and the Crimea, and always bestrode Arabs there, have brought them out when possible. Among these is Captain W. C. Kerr, V. C., of the Royal Lancers, to whom belongs the beautiful AngloArabian Khaled. Of him he says, 'He is good enough to hold his own against all comers on the flat, or between the flags, to carry a first flight fourteen stone man in the shires; would mount the Prince of Wales to perfection, at the head of the Tenth or Lady Clara Vere-de-Vere in the Row.' He owns also 'Speed of Thought,' a dark rich chestnut without white save a star. Possessed of superlative quality from head to heel, high-couraged, full of what Americans term 'vim,' strong, vigorous; his bold, free, and jaunty walk quite up to five miles an hour; he is ever the theme of general admiration. Across country he is as clever as a cat, will face anything, no matter how big, how yawning, and on parade bears himself bravely, as becomes his ancestry."

And do these believe that no other than the true Arabian is of absolutely pure blood?

"This intelligent company of scientific breeders believe, after many years of experience, that the blood of the true Arabian must be the foundation of everything that is excellent in the various types of light horses for the turf, the field, war, pleasure, or light 
harness. Also that each type must have recourse to a fresh infusion of the parent blood, or it will deteriorate. For many thousands of years we know cer. tainly, that his blood has been maintained unalloyed, although among a very small section of the numerous tribes that roam the desert. They prize this blood so highly that they will never cop it and rarely part with it." 


\section{CHAPTER XI.}

\section{ENGLISH AND RUSSIAN HORSES.}

AER there many types of English horses?

"There are several well-established types, most valuable in their different spheres in England. The thoroughbred ranks first, and it is a mistake to suppose he is good for no other purpose than racing, but he is very costly as an all-round horse as well as a racer."

What are the heavy-draught horses?

"First, there is the Suffolk breed of sorrel carthorses. Second, the Lincolnshire horse, called the Shire. Third, the Clydesdale, a first cousin to the French Percheron. Of coach-horses and roadsters there are, first, the Cleveland Bay, and second, the Norfolk Roadster. Some of the ponies are very distinctive."

Is not the Suffolk cart-horse very popular?

"Ah, yes, and he owes his popularity to the fact that he is founded on Arab blood. He is the grandest and by far the best heavy-draught horse in the world. As I know all breeds I have no hesitation in placing him above them all. His gay proud carriage, indomitable courage, gentle temper, and beautiful appearance place all compeers in the show-yard at a disadvantage. And I must be honest and say 


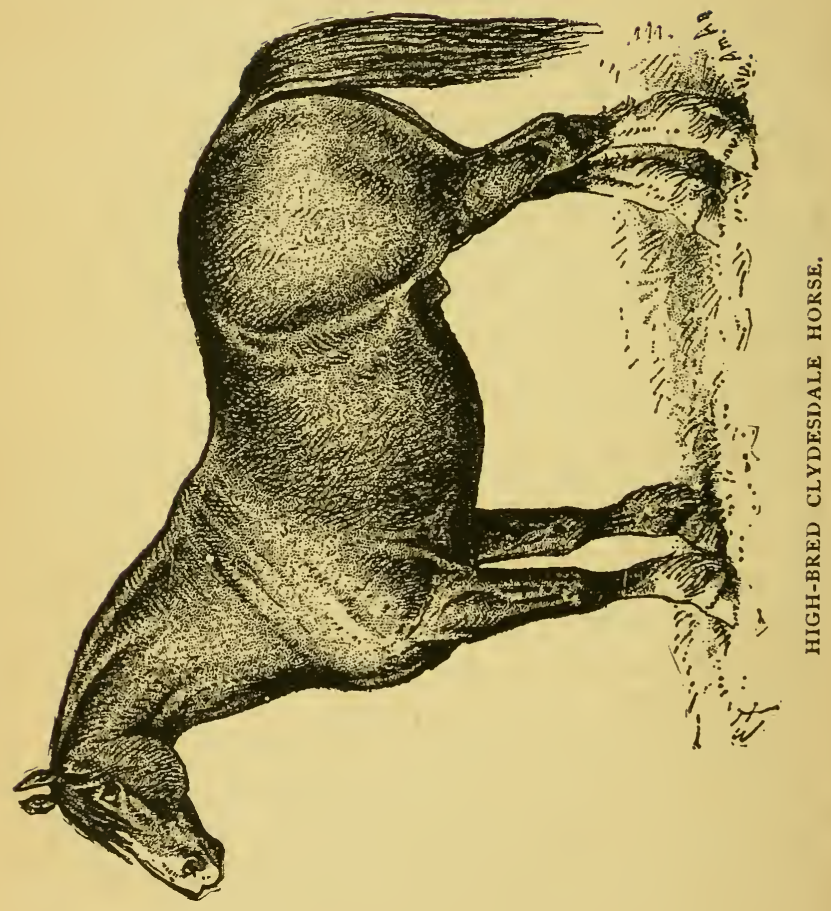


that he owes all these good qualities to the large infusion of Arab blood he possesses."

This matter of breeding must be one of very grave importance.

"Ah, madam, those who proceed on ignorant and unscientific principles, encourage largely the breeding of mongrels. Many are so prejudiced and carried away by the fashion of the day that they cannot see the harm they are doing, and they will not be warned in time."

Have they no other Arabs in Russia than the Orloffs?

"There is a stud in Russia where the Azeel Arab has been bred for a century. It began with the purest blood attainable-most likely stolen-and the system of selection has always been carefully carried on. The object has been to produce such a race of superlative hunters as would mount the owner of enormous estates and his huntsmen, fit to run with his noted pack of wolf-hounds. Captain Kerr writes interestingly of his visit to Russia, and of his experience with these Arab hunters and the hounds. He says: "These hounds hunt by scent as do our stag, fox-hounds, and harriers. The runs are often fast and always long. The wolf can travel both fast and far, and the Duke of Beaufort with his crack pack could make little of the yaunt untiring wolf of Brittany. Over and over again on good, sound, wet ground I have tried to spear a wolf, but on even the fastest race-horse I could never get within striking distance. When I put on a spurt Mr. Wolf would just lengthen his stride, seemingly without an 
effort, and keep his carcase out of reach of my longest arm. Many of the runs when the scent was good would mean thirty miles and more, as the crow flies, of continuous galloping. This was followed by a long weary trudge home, and it was only these Russian Arabs, so carefully and systematically trained, that could overtake the wary, cunning, and tireless wolf, and give their riders the chance for successful slaughter."

They appreciate the Arab in India also, I have heard.

"In Bombay there is a community of merchants called 'Bâttiâs,' who deal mainly in shirtings. They have accumulated much wealth, and it is their particular fad, to ride to and from their offices in buggies, with an Arab in the shafts. These lighthanded mild Hindoos are skilful drivers, and get far more trot out of their horses than do the Europeans. The high knee action, an inheritance from coarse breeds, is conspicuously absent in these graceful Arabs, and a good many of them pace."

I have heard it said that "A Spanish gypsy girl, a pure Arabian, and a game-cock are the accepted embodiments of beauty, symmetry, and graceful motion."

"Yes, that is an old saying. The pure-bred Arab of the desert is trained to be graceful. His rider needs not the bridle to guide him, but indicates his wishes by the pressure of his knees and legs. His head is not jerked, nor his mouth torn, by cruel bits, but a sign, a pressure, a whistle, or a word, is only necessary to establish a perfect understanding. For 
centuries he has been trained and broken by intelligent kindness, which his intelligent instinct fully appreciates. He regards man in the iight of an intimate friend, while he acknowledges his mastery and obeys him lovingly. Well he knows him by the sound of his voice, the smell of his garments, the sight of his face. In all are they in sympathy and accord, and so nothing stands in the way of perfect temper and disposition, which the Arab horse possesses by right of a long and ancient inheritance. His thorough docility causes him to be easily trained to unaccustomed work, to a change of step, to harness rather than the saddle, and to pull rather than carry."

You have never explained to me the different gaits of a horse.

"The gallop is the natural gait of a horse. A pacer goes first on the two legs on one side, and then the two legs on the other. This makes a very easy rocking motion, and is natural to many horses, being generally inherited. The natural gait of the camel is to pace, and that is why it is not difficult or tiresome to ride on an animal so awkward looking. His speedy trot is another thing."

What is the simple step or single foot?

"It is one foot on the ground and three up. The quick trot is the same, but with such force that the body is propelled forward with one leg."

Is trotting then an artificial gait?

"Emphatically so, although in some the gait is more readily acquired than in others. Horses must always be broken to trot steadily, and it is consid- 
ered the most desirable step. To gallop or run the horse throws his forefeet forward, and propels himself with his hind feet. This is his natural motion, and so it is why a horse is said to 'break' when he relieves himself by going from a fast trot into a gallop." 


\section{CHAPTER XII.}

CRUELTY OF DOCKING.

Will you tell me, Count, if there be any conceivably good reason for "docking" a horse, except as it may have captivated the fancy of horse-owners, who regard "style" as the only requisite in their handsome turnouts?

"There is but one excuse for the cruel custom, that it is possible to imagine. When a horse is fretted through constant jerking and pulling on the driving-reins, he may have acquired the habit of seeking for them with his tail. Such wonderful strength has he in that member that by holding down close what so torments him, his mouth for the time being is relieved."

Then inexperienced drivers who tug continually at the reins and saw the mouth intolerably, sometimes teach their horses this bad habit?

"It is true. Horses are very cunning in their modes of personal defense. If one be viciously disposed, it is when his tail has secured the reins, and he can forcibly hold them down, that he may take the bit between his teeth and show his driver as little mercy as has been vouchsafed himself."

Ah, yes, then he can run away or kick the carriage 
to pieces, or revenge himself as he pleases; but is it not the young horse who is docked before he can learn such tricks?

"A colt may show, possibly by inheritance, the disposition to be easily fretted, and then if his master approve the cruelty, he has little chance of escaping it; but only extreme age protects a horse from being docked if his master see fit."

Has the custom been always fashionable, or is it not a recent fad?

"It has descended to us as a relic of barbarism, and belongs to an era, far less intelligent and christianized, than the present century. There was a time when the scriptural injunction 'If an eye offend thee pluck it out' was literally followed; and when an insult was offered from man to man, it was met by a speedy and unerring sword-thrust. So when a driving horse showed a disposition to interfere with the reins by using his tail, the suggestion, 'Cut it off,' seemed the easiest and quickest way out of the difficulty."

Was there no plea for mercy for the noble brute, who instinctively protected his suffering mouth, or no hesitation at committing so wicked an outrage upon him?

"None whatever in those days, and hardly any in this enlightened age, as a drive in any of our fashionable parks will prove. There you will see that mutilation takes the place of personal beauty, and docking is, forsooth, called 'style.',

But tell me, Count, of what particular or important use is the horse's tail? 
"When the gad-fly lights and stings, or the pumpfly-so called because its sting once inserted, it pumps the blood and poisons it-or when any insects persistently irritate the sensitive skin, the long hairs of the tail have power to switch them off. The tail is usually long enough, to reach all along the body up to the neck. About the fore-legs the horse can reach with his nose, and thus defend himself in those parts. As the point of his nose is his touch-point and the sense of a thing is conveyed to him with it, just as we examine an object with our fingers, so is the tail important also, as a part of his sign-speech."

Please explain what you mean by his signspeech.

"Does not the dog wag his tail to give expression to his delight? and does he not hold it down close between his legs, to show his humiliation at angry words or any form of punishment? By the same token, does the horse lift his tail prondly when in motion, and wave it to and fro like an ostrich plume, when he is happy and pleased. One of the surest signs of good-breeding is the spring of the tail from the crupper. Then it can give also a direct blow, blinding, disconcerting, paralyzing, to the too familiar, when the intelligent beast knows he need not kick in self-defense."

Live and learn! I had never thought of all these accomplishments!

"Then when the head hangs wearily down, the tail drops also, and these are signs of great fatigue after hard work, or a long day's toilsome journey. The merciful man notes all these familiar signs, 
and gives to his faithful servant the rest he needs."

Is the operation of docking a very severe or painful one?

"To explain why it is a fearful ordeal, I must give you a short lesson as to the anatomy of the horse's tail. First, there are from fifteen to seventeen bones. There are two pairs of tendons to lift the tail up and to draw it down, and there are two pairs of tendons to turn it sideways from left to right, and from right to left. There are strong ligaments joining the bones, and arteries, veins, and nerves intertwined throughout. Covering all, with Nature's perfect finish, is the muscular tissue from which grow the long heavy hairs. Therefore, to cut through the quivering flesh, the bones and tendons and ligaments, to sever the great arteries and the smaller veins, and to expose the shrinking nerves, is not only to produce exquisite agony to the terrified helpless being, but the operation being of so dangerous a nature, must necessarily be prolonged beyond bearing."

Are the nerves of a horse very sensitive?

"That no animal, not even man, has such an excessive development of nerves as the horse, has been proved over and over again by post-mortem examinations, betraying the closeness with which they are interlaced. With this exceedingly fine nervous constitution. are given the patience and pluck, to endure longer, more severe pain than any other animal living. In comparison to his size he possesses also a very small stomach, and the power to endure longer and more tedious work." 
Then to "ride a willing horse to death" is no unmeaning adage?

"It takes its source from the fact of the heavy burdens put upon the patient animal from time immemorial, to satisfy his exacting and capricious master, Man." 


\section{CHAPTER XIII.}

OPERATION OF DOCKING.

Have you ever seen the operation of docking performed, Count?

"Only once, and then I was called in as surgeon to save the life of the suffering victim."

Will it be too harrowing to hear how it was done?

"The horse was tied by the neck to a ring in the wall, as he stood in his stall, with a switch screwed as tight as possible on the end of his nose. This was in order to hold his head very high and make him powerless. Two men held him against the wall, another cut with a pair of scissors the hair where the tail was to be severed, while a fourth attended to the roasting iron in a small furnace."

Did not the poor dumb creature know something dreadful was about to happen?

"Ah, if you could have seen him tremble with apprehensive fear! When all was ready, there was a sudden click of the large shears, the tail lay on the ground, and the blood spurted from the various veins, striking the wall several feet distant. Then the saucer-shaped iron, heated to a white heat, was fitted, over the bleeding wound, and held there until it was sufficiently roasted." 
And did the poor horse bear this cruelty patiently?

"He endured it bravely until the hot iron was applied, and then the dreadful heart-searching scream he gave, I shall never forget to my dying day-and I never saw him afterward without a choking sensation of tears in the remembrance."

Do horses always survive this cruel operation?

"By no means. Many die of lock-jaw, in torture so prolonged (in the hope that since they have money value they may recover) that both owners and operators are in dread lest the public may learn of the tortured animal's sufferings. The 'Society for the Prevention of Cruelty to Animals' has aided the enactment of the strictest of laws against docking and any man permitting or performing the operation is liable to imprisonment and a heavy fine."

It cannot be painful to bang the tail, and is infinitely prettier, is it not?

"Most decidedly. A woman does not suffer when the ends of her long hair are trimmed, and a banged tail is effective, giving the idea of neat grooming. Then the hairs can be cut quite short, as the stump of the tail is never longer than fifteen to sixteen inches, and seldom more than twelve. No idea of mutilation is suggested by banging."

I have seen horses whose tails seem to have no natural spring.

"Yes, but they are presumably of coarse breeds. It is a natural defect which can be remedied, by cutting slightly the tendons or ligaments which hold it down, even as you would cut a child's tongue who is 
'tongue-tied.' Then the tail must be artificially propped and the wound will heal quickly."

There is no danger in this, I suppose?

"Yes, even this slight operation is dangerous to the horse, and he suffers much pain."

Do you consider the mane also so important?

"The mane and forelock should always be cultivated, for they are a very great protection against sunstroke. To cut off the mane is therefore to uncover a sensitive part of the neck and head, to annihilate a beauty, and to defeat Nature's meaning in her wise bestowal of what she deems a necessity, or she would not have given it. What would you think of a little colt coming into the world with an ass's mane and a docked tail? Would you admire it?"

Well, it might bring its owner an income as one of Nature's freaks, like the double-headed calf or the four-legged chicken, if exhibited in a menagerie. But I doubt if a horse, artificially deprived, would be seen in company with one ready made, so to speak, born with a banged mane and docked tail.

"Of course, madam, you know that all accounts of the prehistoric horse, which was little larger than a sheep, prove his tail to have been prehensile. To him it was as much of an absolute necessity as it is to the monkey to-day. He finds it indispensable as a hand in climbing from bough to bough, in swinging forward to catch the swaying limb of a tree, and in all his nimble movements a wonderful means of defense, progression, or escape."

And you consider the tail of our modern horse as 
essential to his comfort, well-being, and personal beauty, although no longer prehensile, as was that of his prehistoric ancestor?

"Undoubtedly, notwithstanding the efforts of a silly fashion to prove the contrary. It is certainly past finding out how any lover of the symmetrical can be approvingly silent, when he witnesses a procession of thoroughbreds, shorn of this most neces- sary of Nature's equipments, but otherwise glorious to behold! In the horse, Nature revels in Hogarth's line of beauty. Starting at his ears she brings her curve about his neck, gently undulating it at his shoulder and along his back, and gracefully bending it about his haunches, so to describe a profile, of which a swaying tail is an artistic necessity."

I agree with you, for whoever saw a picture by Schreyer or Fromentin, or De la Roche, or Rosa Bonheur, wherein these distinguished artists, who have studied and know the beauties of the animal, would consent to depict him after the performance of this brutal operation! I am sure the question of preference can never be given to the ridiculous bob-tails, who lift the abbreviated remnant of their hind-quarters like a pompon, absurdly suggestive of a certain fashion in bonnets, or hold it down closely as if ashamed of it; but to those who still possess what Nature so emphatically designed and intended they should have.

"Ah, but it is the moneyed classes who give the cue to the horse-using world, and who find it easier to copy an inhuman abuse, than to enlighten fashionable Goths." 
I have heard and read of many horse lovers in this country who refuse to buy or own animals so shorn.

"Yes, there are breeders and buyers here who will not have a horse that is docked, and through their efforts the long-tailed saddle-horse is steadily becoming more fashionable. European governments will not buy one that has been docked for cavalry purposes. It is also well known that officers are not allowed to ride them, even if they be private property, when on military parade."

That is surely a step in the right direction and ought to be encouraging to the Anglo-maniacs to abolish the abuse also in this country. Let us hope that Dame Fashion will interfere and set her arbitrary seal of disapproval, on this cruel and ugly custom of equine mayhem! 


\section{CHAPTER XIV.}

THE MEXICAN BIT AND CURB.

What do you think of the Mexican bit, Count?

"Ah, madam, it is a fearful piece of machinery. Just as the custom of docking descends to us from barbarous times, so is the Mexican bit a remnant of the Spanish Inquisition. It cuts without mercy or relief, every part of the animal's jaws. To place it in any horse's mouth, whether tender or hard, and then to pull against it with the reins, is to produce a torture rivalling the thumb-screw or the rack. While these may not kill or break any bones, as we all. know, they have too often made many a sufferer forswear his religion, or swear to secrets he never heard of."

Is this bit frequently used?

"Not nearly so much now as formerly. Possibly among the ranchers in the far West, or among the Mexicans, whose ponies are hard to break, and whose hearts are quite indifferent to any cruelties inflicted on animals."

Have you any knowledge or cxperience of these bits personally?

"Some years ago I knew a man in Philadelphia, from whose livery-stable I occasionally hired horses. One day I missed from his stall a beautiful young 6 
stallion of Arab descent, who always whinnied at my step, expecting his frequent caress. The man, with a sad shake of his head, told me the result of having hired him out to two young men who were very ambitious to drive him. $\mathrm{He}$ warned them that the horse was not thoroughly broken. 'In what way?' said they. 'Well, you see, he is very good under the saddle, but objects strongly to being hitched, and it isn't everybody who can manage him.'

" "Let us have him, and we will break him to harness for you.'

"'All right,' said the proprietor, "he has cost me a pretty penny kicking things to pieces, but if you've a mind to try him don't forget I warned you.'

"'Well, we'll take him and tame him, too, but first I'11 go for my Mexican bit.:

"Returning shortly, he placed the bit in the young horse's mouth, and the horse was finally hitched to the buggy. As he was led out of the stable he pranced proudly and playfully, lifting his feet daintily, and glancing from side to side, already uneasy at what seemed ever approaching his hind legs. A tug at the bit warned him to go quietly, and he proceeded, still uneasy and half-scared, until the smooth country road was reached."

Then did he run away?

"No, but he protested with his hind legs, for he had felt the insulting whip, and his mouth! The cruel two-edged sword was doing its work, cutting into his palate, his gums, his tongue. In vain he tried to run away from the agony of it, but the bit 
held him! He could not shake it off or ease his aching mouth. The blood flowed down in streams, until his breast and fore-legs were red and dripping. Maddened with pain and fright he went at a furious pace for an hour or so, returning at last to his stable." And had the bit cured him of his youthful spirit?

"Alas, yes! He was not only completely conquered and subdued, but his jaw was rendered helpless, and his tongue so cruelly cut that he could never carry a bit again. From that time on his spirit was broken, and he was unfit either to ride or drive. So much for the Mexican bit!"

And what became of the poor fellow?

"His owner could make no protest against the cruelty, and had just sold him to a breeder, who, knowing the immense value of his blood and ancestry, could make him useful in the stud."

There can be no such objection to the curb bit?

"No, the curb bit is, on the contrary, not only useful, but essential. It is a far more merciful means of reminding a wilful horse, that he is not to have his own way entirely. It does not cut and cause the mouth to bleed."

How does it act?

"It creates an ache in the jaw, which few horses enjoy, and which in most cases effectually controls, while it does not injure them. The curb is most important in riding, especially with fiery young steeds, when mounted by daring women. As a general thing, women have a light touch on the reins; and one properly taught, soon learns when it is necessary to use the curb, and how much of it her horse 
can bear. With some horses it is dangerous even to let go the curb, while with others the snaffle or guiding-rein only is necessary."

Horses are very differently broken, are they not? "While some have hard mouths, which means a greater strength of resistance in the jaw and a defiant way of showing it, others are so tender that it seems cruel to use the curb. Force and will in the rider are not to be always foremost in guiding; but a coaxing word often makes a good understanding, and the horse is most sensitive to kindness. His ears are quick to catch a caressing sound. Few are really vicious by inclination, and it must be some remembrance of a cruelty during their early training which makes them so."

But horses are widely different in disposition, are they not?

"They are the same as in man. Did you not read lately of a horse trampling not only his master, but his master's little son to death?"

You refer to the stableman in New York who had owned and fed the horse for four years?

"It is the same. That horse must have been a Percheron, for they are singularly revengeful and never forget an injury."

But what could the man have done, to provoke the horse to commit such a horrible deed?

"Some men are naturally overbearing, and take no trouble to win the affection and good-will of the animals under their charge. This man may have pun. ished the horse unjustly, or have teased him or neglected to feed him, or have done many other things 
which were offenses from the horse's standpoint. The Percheron is slow and sullen and never forgives nor forgets."

Are they not especially valuable as draughthorses?

"Immensely so. They are never speedy, but have enormous strength and endurance, being founded on Arab blood, and can pull for so many hours a day, and so many miles an hour, tremendous weights, and show no fatigue. The express companies own a large number of Percherons for which they pay the stated sum of $\$ 333.33$ apiece, or $\$ 1,000$ for three."

Did you ever see a horse injured by thrusting a cold metal bit in his mouth?

"That is of too frequent occurrence for me not to have seen it, and far oftener than I like to think of."

One cold frosty morning I heard one boy say to another, "I dare you to put your tongue on this iron lamp-post." In a twinkling the boy did it, and the skin of his tongue was.left on the frozen iron. I was indignant at such an outrage, but had no time to interfere. Would a cold bit have a similar effect?

"Certainly, madam. The horse's tongue is equally sensitive, and a frozen bit, whether of steel or iron, has done infinite mischief to the poor animal, which could never be accounted for. Many a run-away can be traced to this unthinking carelessness or ignorance."

It should not be difficult to remedy.

"A cold bit can be quickly warmed by thrusting 


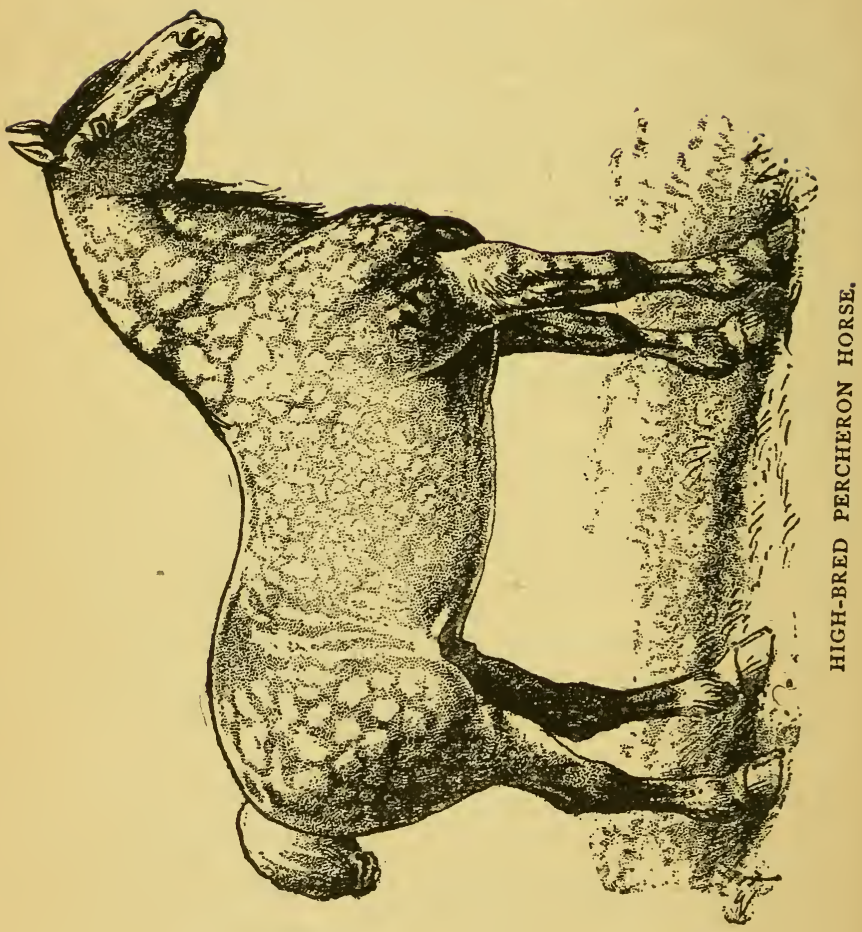


it between the arm and body for a few moments, or rubbing it between the hands, or on something woollen. But to avoid the trouble permanently, through ignorant grooms, the bit in winter should be covered with leather or rubher to prevent such prolonged and intolerable suffering."

The tongue so injured must take a long time to heal?

"It is as severe and painful as a bad burn, and no horse should take the bit after such a misfortune, until entirely recovered." 


\section{CHAPTER XV.}

THE BEARING-REIN.

WE have never heard your sentiments about the bearing or check-rein, Count, but from my own knowledge and limited observation I am almost sure you do not approve of it.

"No, madam, I cannot approve of anything, which makes of a knowing horse simply an automaton, and deprives him of the chance to exercise his natural intelligence. The bearing-rein is a near relation to the Mexican bit, although its invention may have been conceived in a spirit somewhat less cruel."

Should it ever be used?

"It may sometimes be used, but sparingly, on a very unruly young horse and before he is entirely broken."

But does it not prevent any natural play of the head?

"That seems to be the object of it, as it holds the head as if in a vise; but without it a colt, if so minded, can put his head down between his fore-legs, and thus gain such a purchase on his hind ones, as will enable him to do any amount of mischief."

I have wondered how a horse can propel himself at all, with the check-rein holding him in so unnatural 88 
an attitude, and appearing to clog any free or easy motion.

"Ah, yes, it is as effectual in $\mathrm{i}^{\wedge} \mathrm{s}$ way as is the handcuff on the hands of a prisoner. A man cannot run far with his hands tied together, the connection between his arms and legs being such that they unconsciously assist each other, and to tie the hands is to prevent any rapid progression."

Then what is the check-rein good for?

"It is supposed to produce 'style' in a driving horse. That is, his head is held up at an angle to his body, at once unnatural and painful, and is kept in a position, that every one must acknowledge, is stiff, artificial, and ungraceful."

Does it not defeat easy locomotion?

"Undoubtedly, producing excessive fatigue, pain, and long-suffering, through the severe strain put upon all the muscles of the body."

The constant use of it must then be an unmixed evil?

"It is so, emphatically. A horse driven daily with a check-rein, will in time have the tendons of his tongue paralyzed. The steady pull, so fixed and constant, strains the muscles of the head and neck, and becomes unbearable in its cruel pressure against the corners of the mouth."

Do they not get callous?

"No, unfortunately; the effect is to wear away the corners, little by little, until a hole is formed on each side of the mouth from which the tongue protrudes. I have seen horses' mouths so worn away at the corners by the constant use of the bearing-rein, 
that there was literally no room left in the mouth for the tongue to lie, so naturally it would hang out, first on one side and then on the other. The horse would prefer to keep his tongue in his mouth, but the tendons being paralyzed and helpless, the poor creature has no volition in the matter."

This detracts considerably from a horse's value, does it not?

"It cannot fail to reduce his value greatly, a hanging tongue being always so unsightly. Imagine a horse held thus firmly by the check-rein; his head high in air, his nose poking forward, his eyes covered with blinders! He must go on, although he cannot see where he is placing his feet. He lifts them high, trying to feel his way carefully; he can only turn his head when he turns his body, in obedience to a pull on the rein, while all the bones and muscles in his strong frame ache. Still, on he goes, prancing or plodding, for there is a cracking whip behind him! He is amiable. He wants to do what is required of him, and it is from this disposition that his encouragement to mend his pace or mind his ways must come-surely not from the stupid clogs that check and make unnatural his gait and thereby defeat their own intention!'

Under the guidance of the check-rein the horse must then go automatically?

"Certainly, for nothing is left to his intelligence, and he has no more volition than a machine. If regarded as such, then is the machinist a bungler in his trade; but it must be very hard for the intelligent horse to understand why his friendly ser- 
vices to man are rewarded only by pain and misapprehension."

As one of the most sensitive and delicate of animals, he is too often the victim of the ignorant and indifferent, in their love of display, and to accentuate their wealth and fashion, I imagine.

"It is true, but those who know how to care for horses with sympathy, and an understanding of their needs and merits, cannot look with pleasure on their distress. Or, when robbed of their becoming equipments of mane and tail, they are held back to prance against the check-rein, while being urged on by the smarting, irritating lash, all their natural aptitudes held in abeyance, in order that they may thus give a 'stylish' effect on parade."

I fancy there must be very few who have not a keen appreciation of their courage and loyalty; their beauty and sagacity; their endurance and power; their affection and forbearance; and above all, their self-restraint under provocation.

"It may be so, but it is to wealth and fashion that we look, to promote the development of these noble animals, and to prevent their being tortured and harassed by inhuman and ignorant abuses." 


\section{CHAPTER XVI.}

\section{BALKING.}

THERE must be some good reason, Count, why many horses, excellent in every other respect, are so given to balking.

"Ah, madam, a balking horse is a difficult subject to deal with, for he represents the obstinacy of ignorance."

In what way?

"I have found that in almost all cases the habit comes from not seeing an object perfectly-as in man, the horse often inherits or is born with imperfect sight. Very many are near-sighted, others are far-sighted, and those with normal sight are really the exception."

Is this simple fact usually known by horseowners?

"If known, much less attention is paid to it than should be. The sight of each horse should be tested, especially when they shy, swerve, scare easily, balk, or appear in any way, from no definable cause, unruly. A horse which shies at everything along the road will almost invariably be found to have short sight."

But what will help this defect? 
"It would seem a very odld proceeding, I suppose, to suggest eye-glasses as a remedy. Many horses, especially speedy hunters, would find such artificial assistance invaluable. So many are unfit for even ordinary work on this account, that only a visit to the optician could prove their one defect; and establish the fact, that but for it, their value need be no less than that of their more fortunate companions with normal sight."

I have read lately that the oculists have made great strides in curing defects of vision in man, without the use of glasses. Even eyes which have been dimmed from birth by malformation have had the power to see well, without glasses, restored by the best specialists. Many examples were given as evidence that errors of refraction were daily cured by treatment, glasses being dispensed with. Dr. W. H. Bates, of New York City, concludes an excellent article in the Nezo York Medical Journal, after recording many cases cured of near-sightedness, supposed to be irremediable, in these words: "The vision, in many cases of myopia, can be improved very much by treatment without glasses, and frequently this improvement is so marked as to render glasses unnecessary." Could this same treatment be made successful in horses?

"Certainly, diseases in man and horse are very similar, but such treatment of the eyes would be very expensive, although probably not more so, than that of many other infirmities. It might prove that the horse accused of vices, such as shying, balking, swerving, etc., had none such from inclination; and 
that the sight, being promptly cured of its defect, relieved the horse of such odium."

Has any other remedy been found for this trouble? "If the object about which a balking horse is in alarmed doubt can be brought to him or he can be coaxed to it, so that he can see it closely, and can investigate it with his nose, in most cases he will be found perfectly willing to resume his journey, and will show his disgust at his own stupidity by a disdainful sniff."

Then you do not advocate force, whipping, or even coaxing?

"They have been tried too often not to produce their own moral. As I have said before the sense of smell is more acute in the horse than any other sense. The point of his nose being his touch-point conveys a subtler and more exact meaning to his intelligence and reasoning powers. It demonstrates facts when scenting danger from afar, a distant object is either magnified or indistinctly seen by his startled and imperfect eyes, and quick imagination. $\mathrm{He}$ is satisfied of its harmlessness when brought closely enough for him to smell of it. If not permitted to examine an object in his own way, he will never forget in passing that certain locality, that something is there which puzzles and frightens him. He will manifest always the same repugnance toward it, the same disposition to shy or balk in approaching it."

One of the most practical ways of curing a balking horse was told lately by a police-officer. It was to lift the fore-leg by the fetlock and hold it up for 
three minutes. On placing the foot again on the ground the horse would go on as if nothing had stopped him.

"Possibly his attention was thus distracted from what had caused his sudden disinclination to move."

Is it not worse than stupid that the driver of ? balking horse will not explain to him the alarming object, whether it be an engine or a scarecrow?

"Ah, dear madam, the horse is too often regarded as a mere machine, without common sense or even common instinct. It is only a man of intelligence who will discover the same quality in his horse and credit him with "horse-sense." "

I notice that expression quite commonly used. What is its real meaning?

"I $\iota$ intends to convey the idea of ordinary intelligence combined with quick and unerring instinct which together prevent mistakes. Many a traveller owes his life to 'horse-sense,' when if left to his own he would have lost it. Afterward with what nervous awe, he has looked upon the frail and narrow bridge, spanning a rushing torrent far below, over which his faithful sure-footed beast has carried him in safety, while the thunder rolled and the lightning flash was the only lantern, to point out the dangerous path in the inky blackness of night!" 


\section{CHAPTER XVII.}

\section{BLINKERS AND BLINDNESS.}

Do you advocate the use of blinkers?

"Many horses are better without them, but it would be not only absurd but dangerous, to drive all horses without blinkers. There is much to be considered in the method used in the early training of a horse; how much intelligence his trainer possessed, and how much he gave the young colt credit for. While some are more knowing than others, all horses have a certain and intimate knowledge of their own power and its limitations, and their inductions are singularly accurate."

Then you believe in the old sarr "As the twig is bent the tree's inclined?"

"It should never be forgntten for a moment in breaking, training, and rearing young horses. They have a surprising memory and often prove the fact to one's consternation. An examination by the optician to test their sight, would also establish the need or abolishment, of blinkers, in each individual animal."

Why do saddle-horses never wear them?

"For one reason, because custom has established the fashion. It is obvious that a horse carrying his burden, can travel on as narrow a path as the rider 
himself, and oftentimes more surely. Riding-horses swerve and shy quite as much as carriage-horses; but the former can be guided to a disconcerting object and so be able to investigate it, while the horse that is pulling a vehicle must be kept in the beaten road."

Is a horse more easily managed under the saddle? "Undoubtedly. A good rider is not so liable to accident as the driver whose horses checked, trussed, and tortured by fashionable harness have their natural action encumbered. Forced as their movements are into an artificial gait, when they become thoroughly alarmed, the ease and dash with which they can throw off all restraining bonds, prove their mighty strength and make man feel helpless in his own inventions."

Then it is not surprising that with blinkers or without they sometimes get unruly?

"They know well the power or lack of it, of the hand which guides them, and the voice which encourages them to do their best."

Is the martingale an essential equipment in riding?

"It bears the same relation to the riding-bridle that the bearing-rein does to the harness of a horse driven. The latter holds up and back the horse's head to an unnatural position, while the martingale pulls it down, to emphasize the arch of the neck."

Then it is not important?

"Not in the least, and there are times when the use of it is very dangerous. Riding with a party of hunters one day, we came to a fast-running stream 
into which one man plunged impetuously, intending his horse to swim the distance. From the horse's struggles I realized in a moment that the martingale was not undone and the horse's nose was below the water line. The frantic animal soon unseated his brave rider, who immediately sank before our eyes, having been kicked in the desperate effort of the poor horse to free his head. He finally found the solid ground under him, and came ashore. But his rider, one of the best horsemen I ever knew, rose to the surface a drowned man; and all our efforts to recuscitate him proved unavailing-I have never since found any use for the martingale."

What are the principal causes of blindness, Count?

"If the nose-bone be affected by disease the nerves of the eyes will suffer, and unless the trouble can yield to treatment, as it does in man, the horse will eventually become blind. Knocking in the head or nostrils, which some human brutes seem to think an effectual punishment; striking sharply with a whip over the ears and head, or teeth from which the enamel is broken and the nerves exposed; all sooner or later affect the eyes and sight. Pulling daily very heavy loads up-hill, and choking with tight collars, as well as the sudden passage from a dark stable to the bright sunlight or dazzling snow, help to produce blindness."

Is it not remarkable the way in which blind horses can go about, avoiding difficulties, sliding off just in time to escape hitting their heads against a fence or stone wall?

"For this reason I would much prefer a blind horse 
to a lame one. Their sense of hearing is abnormally developed. They listen always to the echo of their own footsteps, which tells them how near they are to an object. Their olfactory nerves also become preternaturally sensitive, and warn them of the approach of persons or things. They know their master by his voice, his step, his smell, his touch, quite as well as a horse that can see. Blindness seems to develop all their affectionate instincts. They particularly love their mate in the stable or in driving; doing their share of work cheerfully, depending on him only for guidance, and if separated will pine and refuse to be comforted."

Then, for all these reasons, he will not deteriorate so much in value?

" His value should not be greatly lessened, as his usefulness is by no means at an end. Conscious of his deficiency, he seems always most anxious to do his best, while any natural wilfulness gives place to the most amiable desire to be led or guided, only that he may do the thing required of him. While there is nothing that more appeals to the sympathies than a blind horse, it is not on account of his helplessness so much, as because of his exceeding willingness, and the surprising cleverness of his sharpened instincts." 


\section{CHAPTER XVIII. \\ TEETH AND TOOTHACHE.}

Is it true, Count, that horses are great sufferers from toothache? I have read that the complaint is the real cause of many a runaway, attributed to viciousness.

"I believe nothing can be more absurd than such a statement. Decayed teeth in a horse are most unnatural. Of course, if the horse be constantly fed on something sour, which creates fermentation, the enamel may become broken or rotted and the nerve may in time be exposed. In this condition a frosty bit will cause exquisite pain; but toothache, as we realize it, is something unknown to a well-kept healthy horse. Filing, cleaning, evening, and thereby spoiling the horse's teeth, is gypsy work."

How do you mean?

"It is the way gypsies often take to earn a few dollars, and at the same time learn the secrets of your stable. The veterinary surgeon knows better, and nothing is gained by constantly fooling about a horse's mouth. In Europe and in the colleges there such things would excite much merriment and contempt-but the subject has been presented to me before in this country."

The age of a horse is told quite distinctly by his teeth, is it not? But I have never understood just how. 
"The young horse's teeth meet in the mouth, edge to edge, being upright. Some horses are parrotmouthed, so that the upper teeth project somewhat, but the back ones always meet squarely. As they grow older the teeth in both jaws project more and more, making an acute angle, until, at twenty years of age, the undersides meet together."

Ah, I see. Did you ever pull a horse's tooth?

"Never, but once. The horse in this case had what are called porcine teeth; that is, four little tusks growing at the sides of the mouth. As they were not attached to the bone, I nipped them off promptly with the forceps with little pain to the horse, who was greatly relieved to be rid of them."

And is this the only case?

"I was called once to come quickly to a horse, supposed to be suffering from lockjaw. After examination I could assure his anxious owner that the trouble was a very trivial one. A tooth in the upper jaw had broken off, and just opposite to it, in the lower jaw, was a tooth projecting nearly an inch above the others. When the horse closed his mouth in eating, the projecting tooth fitted nicely into the hollow of the broken tooth above, and became wedged or locked."

What did you do?

"It was very simple. I pried open his mouth with a chisel and filed off the long tooth, so that there was no further danger of its locking-an operation which the horse seemed to understand, and bore very patiently." 


\section{CHAPTER XIX.}

LOCKJAW.

Is lockjaw a common disorder?

"Fortunately not, being very dangerous."

What produces it?

"Such similar causes as produce it in man. A nail cutting a nerve in the foot, sometimes a splinter of wood, or wounds which cause great inflammation and poison the system. Unless great care be taken in 'docking,' lockjaw is likely to follow the operation, and it is seldom that a horse so afflicted can recover. A large proportion of horses docked die of lockjaw."

Have you seen the late controversy about corns on horses' feet, Count, and do you consider them curable?

"Certainly, they can be cured, if great care be taken in shoeing, for it is the shoe which produces corns. The quarter-hoof should never have a nail in it, as it is in the corners where come the bars and the crust that the corn has its beginning. A careless blacksmith will cut the bars and open the frog, and thus open the hoof, into which dirt and mud enter and find an abiding-place. That part of the shoe which goes beyond the quarter-hoof does not even pretend to fit the foot sometimes, but curves 
downward, making an effectual recess between the hoof and shoe, for the accumulation of dirt and even small pebbles. These foreign substances, if not at once carefully removed, will soon produce corns, which if in turn grow too high will develop quitor."

What is that?

"It is a species of tumor. Then an operation must be made by cutting this tumor open, when suppuration will follow and the corn can be permanently removed."

Then horses who have never worn shoes do not have corns?

"Certainly not. Corns are the inevitable result of careless shoeing. Many other evils also follow upon the indifferent, not to say cruel handiwork of the blacksmith. I have seen the crust of a horse's foot perforated like a sponge, nail upon nail having been driven into it. Every nail, more than is absolutely necessary, not only helps to impede the horse's progress, but causes him often great suffering. Nobody should own a horse who cannot afford to have him properly shod, or who will permit him to wear a worn-out shoe, simply because it still clings to the hoof. The lamina is exceedingly sensitive, and iron nails pressing close against it are a frequent cause of lameness. The shoe should be nailed neither too high nor too close to the heel. All owners of horses, whether for the saddle, the carriage, or the plough, should look to it that no false economy in the matter of proper shoeing, and frequent renewals should tempt them to reduce the value of their animals, as well as to cause to them great pain and suffering." 
Have you seen many horses made lame by imperfect shoeing?

"It is only too common a fault. Only lately a physician called me to look at his horse, remarking at the same time that he thought 'the horse must become lame on purpose, for he couldn't discover anything the matter with him!' He said further, 'The horse will go all right for ten minutes or so in the morning, and will then suddenly go lame, and continue so the rest of the day.' Well, I examined the horse carefully, although my eye had lighted on the real cause at once, and I said: 'Now, doctor, you are pretty wise, and know the proportions of a horse and his defects. Stand exactly in front of him and tell me if you can see nothing wrong.'

" 'No,' replied the doctor, 'I'll be switched if I can, and I believe he is playing off, the rogue!'

"'Will you kindly look at his shoes?'

"The doctor lifted first one hind foot and then the other. 'Nothing the matter with them, Count.' "'Well, go on, finish your inspection.'

"He lifted one forefoot and then the other and a sudden light began to dawn on his visage: 'Ah, can it be so simple a thing?'

"'It is that, and that is all,' said I, and by actual measurement the corks on the shoe of one forefoot, were a full inch longer than all the others, and so lifted the horse just so much more from the ground."

You had the laugh on the doctor that time, Count.

"Yes, I had, and he went off half mad and half 
pleased, when I told him to go home and walk around in shoes, one with a heel and one without, and see how lame he'd go, without trying."

There are many different causes for lameness, of course?

"So many that it is a proof of much care, that we see so few lame horses in the street. An unprincipled stableman, knowing all the tricks of the trade, in order to spare himself a day's uncongenial labor, can quickly lame a horse, without doing him more than a passing injury. These things are so common that before examining a horse just developing some trouble, I make a sort of detective's inspection of the groom, and seek to learn something of his habits, inclinations, etc. A pin in the fetlock, a hair from the tail, threaded in a needle, and run through the outer and middle tendons of the front leg, and cut off close so that nothing appears, are some of the detestable tricks occasionally resorted to out of petty revenge, which I mention only as a warning to trusting owners."

What are your notions about clipping, Count?

"Among some of the best horsemen there is a strong prejudice against clipping a horse, thus depriving him, during the cold weather, of the warm coat Nature provides. It would be most cruel to do this, when a horse, by reason of neglect, was permitted to stand after heating exercise, without being well blanketed."

I suppose the argument against clipping is that it is against nature?

"Yes, that is the strongest argument, but as stab- 
ling, driving, and even domestication, are all artificial conditions it cannot well stand."

But does he not take cold more readily without his winter's coat?

"On the contrary, a horse with a heavy coat is all the better for being clipped, and is not nearly in so much danger of taking cold. When brought in 'sweating' his heavy coat will not dry out readily, and unless 'worked' an hour or so to cool him off, will chill and shiver, even under the blanket, and that dread foe, pneumonia, may follow. A clipped horse is rubbed dry in a few moments, and being wrapped in his warm blanket, he is in a glow very soon. Experience proves that he eats better, feels better, will do more work cheerfully, and will even keep in better condition and sounder health on less food."

Clipping certainly improves the appearance vastly. "No doubt of it, giving the idea of excellent grooming and care, so immediately detected in the horse's coat, and I believe it adds greatly to his physical comfort and well-being." 


\section{CHAPTER XX.}

ARAB HORSES IN SOUTH AMERICA.

ARE not Arab horses a specialty of some of the South American states, Count?

"It is a matter of history that when Pizarro conquered Peru in the sixteenth century, he carried from Spain less than a score of Andalusian Barbs. The natives had never seen a man riding astride of an animal, and their wonder deepened into terror and dismay, at the near approach of this little band of Centaurs. Seeing the four legs surmounted by a human body and head, and in their crude superstition imagining it to be some new species of avenging animal, the Inca natives fled, conquered by their fears. Amused by this easy conquest of the Lower Country, Pizarro took his army of vagabonds, gathered in Panama and amounting to about one hundred and fifty men, led by the score of mounted Barbs, to the royal city in Peru of the reigning Atahualpa. Him, he took prisoner after getting possession of the city.

"Discovering shortly Atahualpa's hold on the affections of his people by the enormous ransom they offered for his redemption, he realized that such a prince would be a dangerous rival to his own influence, and ordered his execution. This was os- 
tensibly, for the crime of unbelief; but it was delayed by the influence of a pious priest, who undertook to explain to the willing, helpless Pagan the doctrine of the Trinity. He was unable to comprehend it, but Pizarro promised him that he should not be burned to death if he would give him a room full of gold. The room which Pizarro signified was filled with gold, but the poor Pagan ruler of the Incas was subsequently butchered by the treacherous Spaniard. The removal of this powerful monarch and the settlement of Pizarro's quarrels with his partner Almagro, brought tranquillity to the conquered land, which was at once placed under colonial government, subject to the Spanish crown.

"Stirring reports of the wonderful wealth in precious metals of this E1dorado having gone abrcad, intense excitement among all classes in Spain was created, of which the immediate result was extensive emigration to the new country. Thus the city of Truxillo, named for Pizarro's birthplace in Spain, was founded in the department of Libertad. Many of this colony of Spaniards were from the families of grandees, and with every ship-load of emigrants came its quota of Andalusian Barbs. These men, easily making slaves of the amiable natives, devoted themselves to agriculture, and became proprietors of vast domains. In the vicinity of Truxillo are still two haciendas, devoted to the breeding of horses, in which the blood of these imported Arabs remains pure to this day. Their progeny are found all over Northern Peru, where they are greatly affected as saddle-horses by military officers, political dignita- 
ries and gentlemen of wealth. They are never harnessed or driven.

"One of the uses to which the Arab's grace, agility, and intelligence especially fit him, is the national bull-fight. This, in Lima, is the most perfectly-placed spect of its kind in the world. No cruelty is permitted there. It is worth the rider's reputation to let his horse be injured, as those ridden are the very choicest from the haciendas. They are trained to the touch of the knee, both hands of the rider being devoted to exciting the wrath of the bull. As the toreador waves his capa, which conceals from the horse, the furious oncoming of the enraged brute, a pressure of the rider's knees against the sides of the perfectly trained Arab, causes him to swerve gracefully aside, and the bull is carried on far beyond, by his own momentum. As he returns to the charge the horse again coquettes with danger, until, to the sound of the bugle, he prances out of the arena, to let a second horse and rider take his place. Should a horse be injured in this dangerous play, instead of exciting the plaudits of the audience-as in Madrid and Mexico, where the most worthless and broken-down are used, and gored to death-the rider would have to encounter the angry curses and contemptuous hisses of the multitude.

"The matador on foot, whose duty it is to finally kill the bull by a sudden and direct plunge of his long sharp sword through the heart-thus causing him no suffering-shows wonderful courage, agility, and cool self-possession. He must strike with unerring aim or his own life will probably pay the forfeit. 
"The scene is one of exciting and pleasing interest to the audience, which may hold its breath in certain portions of it, but only as we do when our acrobats take a flying leap from the topmost height of the circus tent. The bull, having been killed instantly, is hitched to four gayly-caparisoned white mules; and as a concluding funereal ceremony he is dragged around the vast circle of the amphitheatre, in order that every individual may get a glimpse of the creature so skilfully slain. Finally he is dragged out of the arena, through a portal under an archway, as another doomed and angry bull comes plunging in, excited and terrified by the noise of exploding bombs and rockets, the loud hurrahs and clapping of hands, and the deafening clamor of the military bands."

There is a new idea in what you tell me, Count, in this fact, that not very far away from us, and on our own continent, are horses of the purest Arab blood, accessible and purchasable, which can be bought for a very moderate price.

"Certainly, madam, and more beautiful and more perfectly trained than any saddle-horse to be seen in New York City."

Yes, I can understand that when it comes to the breaking and training of horses we know very little about it in comparison to those who are entirely dependent upon them in their journeyings; whose travel is all in the saddle; who know little of railroads and almost nothing of ordinary wheeled vehicles. 


\section{CHAPTER XXI.}

\section{ARAB HORSES IN NORTH AMERICA.}

Since all European Governments recognize the importance of Arab blood as the foundation for their national horses, has America been clever enough to take the cue from them and follow their example?

"Until r86I, the initial year of America's civil war, the foundation blood of her finest horses was the choicest from England's thoroughbreds. This was always kept strongly reinforced by infusion of the blood of Arabian horses."

And was America able to secure them notwithstanding the many difficulties of purchase and importation?

"An Arab stallion now and then found his way to America, through the persistence of travelers in securing them, either by fair means or foul. Their coming has not only always made a sensation, but the histories of their departure and their arrival here, have more or less of romance and mystery attached to them."

There is no doubt of that. I have never heard anything about any individual Arabian horse that was not interesting, possibly because of the mystery that seemed to surround him, and the very natural 
wonderment and question in one's mind as to "how did he ever get here?"

"Yes, that is the first question one naturally asks: for stratagem and not strictly fair dealing has been the means of securing most of them, except when they have been presented by the rulers of the countries whence they came."

What is the earliest mention of their importation to this country?

"About the year 1600 the arrival of two famous Arabians is mentioned, one called 'Abdallah,' and the other, Lindsley's Arabian, 'Ranger.' These were the first known progenitors of Arab blood in this country. Several horses have been called for the first who were Abdallah in name only, and not in blood, as has been erroneously supposed."

And what Arabians have come to us in this present century, Count?

"As early as i 820 Charles D. Cox, United States Minister to Tunis, who married the daughter of the Bey of Tunis, was presented by the Bey with two Arab stallions, one a chestnut and the other a sorrel. They were sent over the seas in a sailing vessel, and landing safely, were kept on a farm in Middlesex Co., New Jersey. The sorrel was the sire of the original 'American Star,' the founder of the noted Star family, and from whom the Hambletonians derive their best qualities."

Was not Stamboul an imported Arabian?

"Yes, and of pure blood. Before the Minister to Turkey, Mr. Rhind, left Constantinople in 1832, he sent over three Arab horses, Zilcaadi, Stamboul, 
and Yemen. The etiquette between the two nations made it impossible for Minister Rhind to own them, and they were sold for the benefit of the United States Government. Yemen was taken to South Carolina. The Hon. Henry Clay and Hon. Mr. Berriman, then senators at Washington, were anxious to secure this noted blood to their own State of Kentucky, and so bought Zilcaadi and Stamboul.'

It must have been their progeny then that have made the fame of Kentucky horses?

"Doubtless, madam, for from Zilcaadi came the famous 'Gold-dust' blood of that State, while Beautiful Bells, the cherished brood-mare, owned by Governor Stanford of California, is a granddaughter of Stamboul on the maternal side. Then, too, the fastest colt ever bred by the late R. A. Alexander of Kentucky was from a granddaughter of Stamboul."

Was Grand Bashaw not an Arab?

"He was a Barb, imported to Philadelphia about I82 I from Tripoli. The Logan family bred and owned young Bashaw, whose sire was Grand Bashaw, and whose dam was Fancy. She was a daughter of Pearl, who was a daughter of imported Messenger, four times inbred to Arabian blood, three times to the Arab Godolphin, and once to Darley's Arabian. Messenger, therefore, was the sire of Pearl on the maternal side."

Henry Clay was not an imported horse, was he?

"No, he was a native born American, but was doubly interbred on both sides to Arab blood. This fact made him a phenomenal sire, and many of 
America's fastest trotting horses trace back their descent to old Henry Clay. The dam of Electioneer was also a Clay."

And was not Electioneer the sire of Arion, who has lately been sold for $\$ 125,000$ to Mr. Forbes of Boston as a two-year-old?

"Certainly, but the dam of Arion was three times interbred to the same blood, which is only another proof of the value of inter-breeding to pure blood derived from the Arab, the primitive."

Is not Arion a near relation of Axtell?

"Both Axtell and Allerton were interbred to the same blood as Arion's."

Is there not an interesting story connected with the rearing of Axtell?

"Ah, yes, and one which proves again the errors of mismating, and the folly of experiments when mongrel blood is used. Also it proves the fact that no type of horse can be created except through Arab blood, and that all game qualities are due to that blood."

Well, what is the story?

"Two gentlemen of Dubuque, Iowa, purchased mares of fashionable name, to breed to the blood of certain other fashionable name in the sires. To their great disappointment the offspring proved an utter failure, and the mares were sold for a song as valueless. Mr. C. N. Williams bought the two for $\$ 225$, and bred them to the same blood he believed the mares possessed-the Clay. Each in time produced a colt. One was called Axtell and the other Allerton. When Mr. Williams had offered mares 


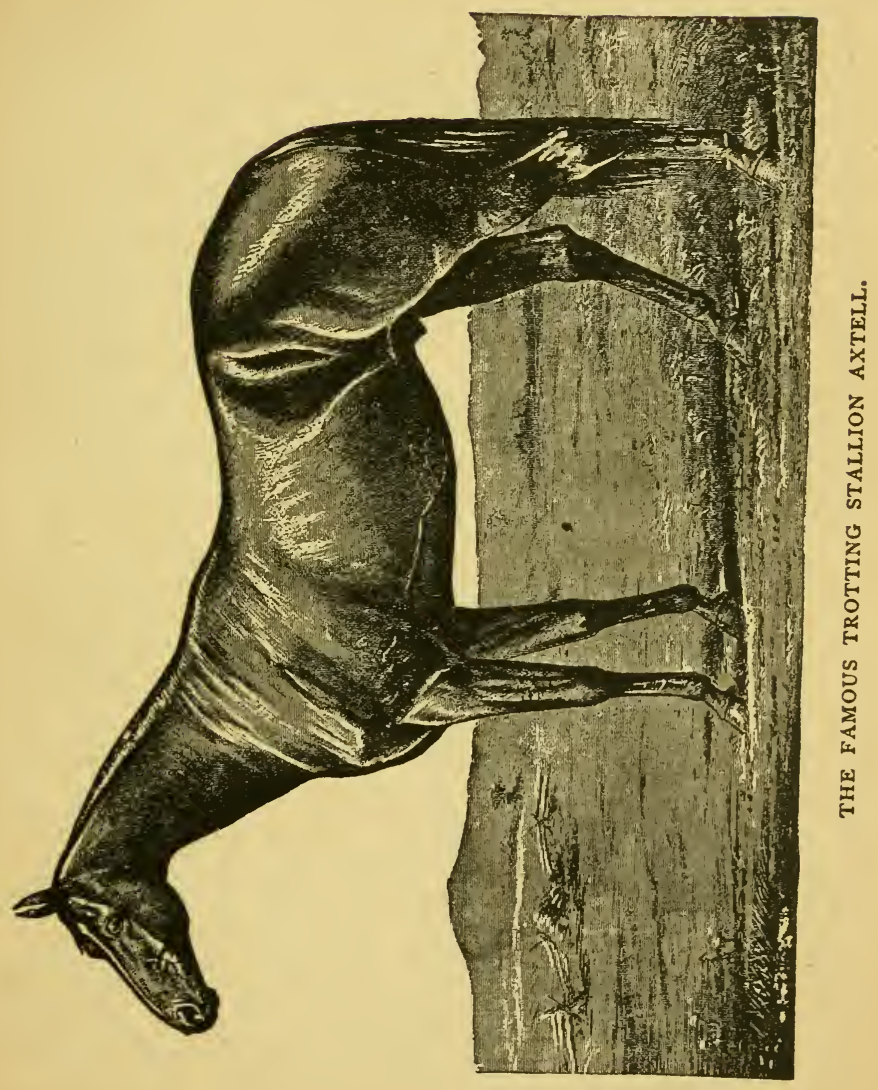


and colts for \$250 apiece, and no purchaser was found, he concluded to train the colts himself. Both gave promise of rare speed. When Axtell beat the record at $2: 12$, as a three-year-old, the offer of $\$ 105,000$ was made for him by a stock company in Indiana, to which he was sold at the price offered."

Then it is to the Arab-Clay blood predominating in Axtell which explains his phenomenal speed? And what became of Allerton?

"Mr. Williams, having sold Axtell, began the training of Allerton, who proved the better horse, for as a four-year-old he trotted a mile in $2: 10$. These two colts are matched against each other for a purse of $\$ 10,000$, but Allerton will not be sold for less than $\$ 200,000$. They demonstrate the blood cause in the most satisfactory manner."

Whence comes the Wilkes family?

"The dam of George Wilkes was a danghter of Henry Clay, which blood made him the phenomenal sire he was. Rysdyk's Hambletonian is credited to the Wilkes family."

Was there not a famous Arab called Black Emperor?

"Yes, madam. Black Emperor was a Barb, although registered in Bruce's American thoroughbred stud-book, as an Arab. He was presented to the ambassador from France in 1857 by the Sultan of Morocco. Mr. Scott, an American, purchased him in Morocco from the ambassador for $\$ 7,000$. He was at once shipped to England and thence brought to America by Mr. Scott, who subsequently sold him to Mr. John B. Hall, of Toronto, Canada. Black 
Emperor left a son whom Mr. Hall presented to his son-in-law, President H. M. Claflin, of Cleveland, Ohio. This son was known as Black Emperor, Jr., a daughter of his-and granddaughter of the imported Arab, Black Emperor-made a visit not many years ago to Abdul Hamid II. of the Americo-Arab Company of Long Island. The result was the colt, Fez, who will be shown at the World's Fair Exposition in Chicago, matching, if not rivalling, anything of his age there on exhibition." 


\section{CHAPTER XXII.}

SECRETARY SEWARD'S ARABS.

DiD not the horses brought out by William $\mathrm{H}$. Seward create some sensation and controversy?

"Undoubtedly so. Mr. Seward was sent to Syria to adjust some difficulties between the two governments. The matter was finally settled in the criminal courts and was so amicably and satisfactorily adjusted that the Syrian government, to show its appreciation of Mr. Seward's clever diplomacy, asked him to express some wish which it was in their power to gratify. Mr. Seward, always interested in the agricultural needs of his country, especially of New York State, replied that if the Syrian government would help him to procure some pureblooded Arabs to send home, they would not only confer upon him a personal favor, but would also benefit the United States more than in any other way. At that time there were some beautiful Arabs under the control of the Syrians. Of these the clerk of the Criminal Court selected a blood-bay stallion, - eight years old, and a chestnut colt, two years old; also a white mare, who, unfortunately, died on the way. They arrived in 1860 , the expenses of their journey amounting to \$10,000.

"Mr. Scward offered them as a gift to the Ncw I I 8 
York State Agricultural Society if the society would pay the expenses of their importation. It was a poor return for Mr. Seward's generosity-even when excused by the great excitement attendant upon the breaking out of the civil war-that they refused to comply with his very just proposal. In this emergency, as he had sought, in the acceptance of the gift, to benefit his country, he presented the twoyear-old colt to Mr. Ezra Cornell of Itnaca, N. Y., and the stallion to Hon. John E. Van Etten of Kingston, N. Y."

And what of their progeny?

"The stallion was known to be the sire of only two animals. One was a gray filly, bred by Judge Westbrook of Kingston, and the other a colt, bred by a nephew of Judge Sackett of Auburn, N. Y. The colt was shown as a three-year-old in the State Fair at Rochester, and won a special gold medal for being the handsomest horse on the grounds. Subsequently he was sold to Canton, Ohio, where he died leaving two fillies only. They are now owned by the Myers' stock-farm at Canton."

What became of the chestnut colt?

"Ah, poor fellow, he died simply from neglect, the war just then causing such absorption of all men's thoughts, that all things else seemed of little importance. At that time many of our best and most noted trotters were always spoken of with pride, as coming from Arab ancestors. Morgan was an Anglo-Arabian, and the dam of Dolly Spanker, an inbred Morgan mare, while Sherman Morgan and Buckshot were doubly inbred to Morgan. Gano was 
by American Eclipse, who also boasted the Arab strain. Thus it was that the Arab blood was spread throughout the United States up to I86r. It was not only known and most highly valued by intelligent breeders, but was considered absolutely essential to the making of a perfect horse." 


\section{CHAPTER XXIII.}

SELIM.

All these imported horses that you have spoken of, Count, were presents or purchased with the consent of the "powers that be." In what cases was stratagem used?

"Judge Richard Jones, of Lower Merion, Montgomery Co., Penn., who had been appointed consul to Morocco from that district, was an exceptionaily honest man. But much against his inclination he finally resorted to stratagem, in order to secure the famous 'Selim.' During the whole term of his consulate, about $r 840$ to 1845 , he tried in various ways to buy this horse who had so captivated his fancy, but the Sultan forbade the sale and export, and the owner fought shy of the judge."

But you say he finally secured him?

"He reasoned with himself a long time before he would admit the temptation which was gradually conquering him. His servant, a native, understood perfectly the struggle in his master's mind, and having become much attached to him, determined to help him.

"'You want Selim, Effendi?"

"'I do, indeed, Rustam, but they won't listen to his being sold.' 
“'No,' said Rustam, shaking his head, 'nobody can buy Selim, he too good horse to go away over the sea. What will the Effendi pay for Selim?'

" 'I will gladly give $\$ 4,000$ for him, but I tell you he can't be bought.'

" "The Effendi is right. If the Effendi try to take Selim, wicked men kill Effendi.'

" "We11, I might as well give it up, Rustam, and as I sail for home in a day or two I must go without my beauty. It is too bad!'

"Rustam soliloquized: "The Effendi sail to-morrow night. No moon-all dark. Four thousand dollars!' Aloud, 'Rustam very sorry, Effendi.'

"With a sharp look at Rustam-'Get out, you miserable tempter! I'm an honest man and must go without Selim.'

"The ship still lay at anchor the next night on a dark sea, lashed to quiet by the torrents of rain that were descending. The judge paced up and down on the covered deck thinking sadly of his disappoint. ment and wondering what caused so unusual a commotion on the ship, when Rustam suddenly appeared before him:

“'What brings you here, Rustàm?' said the startled judge.

"'Rustam steal Selim away! Effendi very good master! Selim here on ship, he go too.'

"You rascal! Is it possible you have stolen Selim and have brought him here on board?'

"With excited affirmative gesture: 'Yes, yes, Effendi. Selim come with me! Nobody know where he go! Rustam take money, put in Selim's 
place! Gold good! Make owner rich! Buy more horse! Too late, now, Selim stay here!'

"The temptation was toc great for the judge, and counting out the $\$ 4,000$ in gold he handed it to his faithful servant, knowing it would find its way to Selim's owner. Not forgetting Rustam's service he rewarded him liberally, and bade him depart, as the ship was about to set sail.

"The judge and Selim arrived in due time and in good condition at the judge's farm. Selim's blood laid the foundation for the finest breed of horses ever raised in that country. His arrival caused a furore among the breeders, all anxious to secure his blood. Among others, Jonathan Roberts, then United States senator, bred to him, and owned several of his colts, among whom were Murad Bey and Selimair. As late as 186 , Selim was sent from Philadelphia and shown at Mineola, L. I., at the State Fair, as a 'noted gray Arab stallion.' He was small, gray in color, and had all the finest points of the 'true air-drinker of the desert." " 


\section{CHAPTER XXIV.}

ABDALLAH.

Has the importation of any other Arab a similar history, Count?

"I remember talking with an old sea-captain some twenty years'ago, and he related these facts: Many years before he had been in command of a trading schooner plying between New York and Morocco. As he was about to set sail from the latter port on his return voyage, he had been very busy all day superintending the shipping of the cargo. The darkness fell early and the night was black with threatening clouds, so that the sailors had quit work, had eaten their rations, and were about to turn in, when the ship was signalled from the shore. Soon a boat lay alongside, and a voice from it desired speech of the captain. After a few moments' conference, he decided to go ashore. As he landed, there stood impatiently waiting, a Moor. Beside him, pawing the ground and sniffing the salt air, was a horse of the most beautiful proportions, and with every mark of the finest blood. The Moor wasted no words in explanation, but requested the captain to take the horse aboard his schooner, carry him to New York, and deliver him in safety to the person to whom he was consigned. There was no time to demur and a 
good round sum in gold being counted out, in payment of the horse's passage, with some difficulty the young Arabian stallion reached at last the deck of the schooner.

"The Moor then confided to the captain these facts. A very large sum of gold had been paid for the Arab, which was of Abdallah breed, with directions that he should be shipped to America. But the tribe, of which he was the pride, and from which he had been purchased, finding that the owner resented their interference in his sale, appealed to the Sultan. The Sultan at once forbade the departure of the horse from the country, and the American consul's authority was also called into requisition to prevent it. While the dispute still raged, the wily Moor was flying toward the coast under cover of the darkness with the result described. The captain remembered well, being greatly impressed by it, how the Moor, to prove his horse's ancestry had pointed out to him the marks branded with a fine needle, which were written on the inside of each foreleg, thereby telling the story of his birth."

And was he the progenitor also of a race of fine horses?

"Unfortunately, no; for he lived but a short time after reaching America."

Then this may have been the "Abdallah" which died on Long Island many years ago, from starva. tion?

"It is impossible to tell, for there is much mystery, and many uncertain statements have been made about the fisherman's Arab, which was allowed to starve to 
death on the Long Island coast. The old sea-captain believed it to be the Abdallah Arab he had brought over, as no trace of him could he find. The Abdallah had never been broken to harness or the plough, and the fisherman, into whose hands it was supposed he had fallen, vexed by his proud spirit, which could brook no such humiliating labor as was required of him, turned him out in disgust rather than be at the trouble and expense of feeding him."

I have heard it claimed by some Long Island natives that the Abdallah who died thus was Abdallah only in name and not in blood; although he was supposed to be the sire of Rysdyk's Hambletonian, whose dam was a Conestoga draught-mare. This horse, Abdallah, it is said, could neither trot nor run, was lazy and vicious, and the fisherman's patience coming to an end, he turned him out to find a living for himself.

"The identity of this horse has never been fully established, but it is plain to be seen that any creature turned out on the barren sands of the Long Island coast would have little chance to find a living, and must inevitably die from lack of both food and water." 


\section{CHAPTER XXV.}

THE AMERICAN HORSE.

Was our civil war so immensely destructive of our best horses, Count?

"Alas, yes! the war almost depleted the country of its thoroughbreds. I had not yet found a home in America, but all Europe rang with accounts of the hearty response, and self-forgetting rush to arms, which was made by men of all classes, in defense of their country and its honored institutions.

Ah, Count, that was but the practical expression of a noble patriotism! There are many large and generous hearts in America, and each individual man and woman longed to help, if only a little. I know that the farmers and owners of valuable breeds offered willingly to the government their most precious possessions, their horses, and begged President Lincoln to accept them. The proportion of horses to men was one hundred to one, and it seems incredible that so many should have been slain!

"It seems so, but those offered were the best and finest in the land, and were the stallions and geldings. The mares were left at home for the very good reason that in battle they are likely to stampede and create a panic through fright. Horses have more nerve. The beat of the drum, the call to arms, the familiar toot of the bugle and horn, and the 
stirring march of the regimental band, are music in their ears, and an impulse to their going."

Very true, and every soldier has something to tell of the surprising and intelligent faithfulness of his horse in battle. How many I have heard grieve over their loss or their wounds! They seemed ever bound together in a mutual love, the soldier for his horse, and the horse for his master.

"Up to that time the foundation blood of America's best horses was the choicest from England's thoroughbreds, which was always kept strongly reinforced by infusion of Arabian blood. For fifty years New England had been proud of her Morgan horse created from Arab blood. New York and Long Island boasted with proper spirit of the families of Henry Clay and Andrew Jackson, while Long Island was the home of the famous Messenger of direct Arab blood, and also of Wildair, inbred to Arab blood. The latter, after importation from England, was so highly prized there that he was repurchased."

Then it was these noted stallions who were the progenitors of the finest horses in the country, and who gave the foundation blood to all the trotting speed of which America could then boast?

"Yes, madam, but when this immense army of horses was sent to the front, the mares at home were left without mates equal to them in blood. Only the basest of stallions, in fact, the commonest mongrels were left to mate with these blooded mares. As the progeny of mongrel blood does not 'train on' with successive generations, the reproduction of thoroughbred horses was an impossibility. From this time 
dates the advent of what is known as the American horse. No heavier blow to the reputation of American horse-breeders could have fallen than this, for it is impossible to create a type from a mongrel of any animal, except a mongrel."

Then it is conceded, after long experiment, that no valuable type can be created, except through the infu. sion of pure blood?

"Yes, madam, we may say that we have an American horse with certain characteristics of much money value to his owner; but does it reproduce with certainty any quality that is in demand by any other nation? Alas! it is only too well proved that the American trotting horse, bred experimentally, in so many cases, does not reproduce two per cent. of trotting speed. From Maine to the Pacific coast the country is flooded with horses which have no type, are uncertainly bred, and unintelligently trained, which are not in demand for export, and at which all foreign nations may shrug disdainful shoulders."

But, Count, are you not very hard on us? Think of our magnificent trotters who beat the world! Sunol and Arion, and Axtell, and Allerton!

"Yes, they have earned a world-wide fame, proving the exception to the rule. But have they not come by accident, as it were, and without any surety beforehand, of their being anything phenomenal? Within the last few years only have the breeders here, with the exception of a very few scientific men, begun to realize their own ignorance and foolish mistakes in getting away from the blood cause. There is a little secret about breeding to 


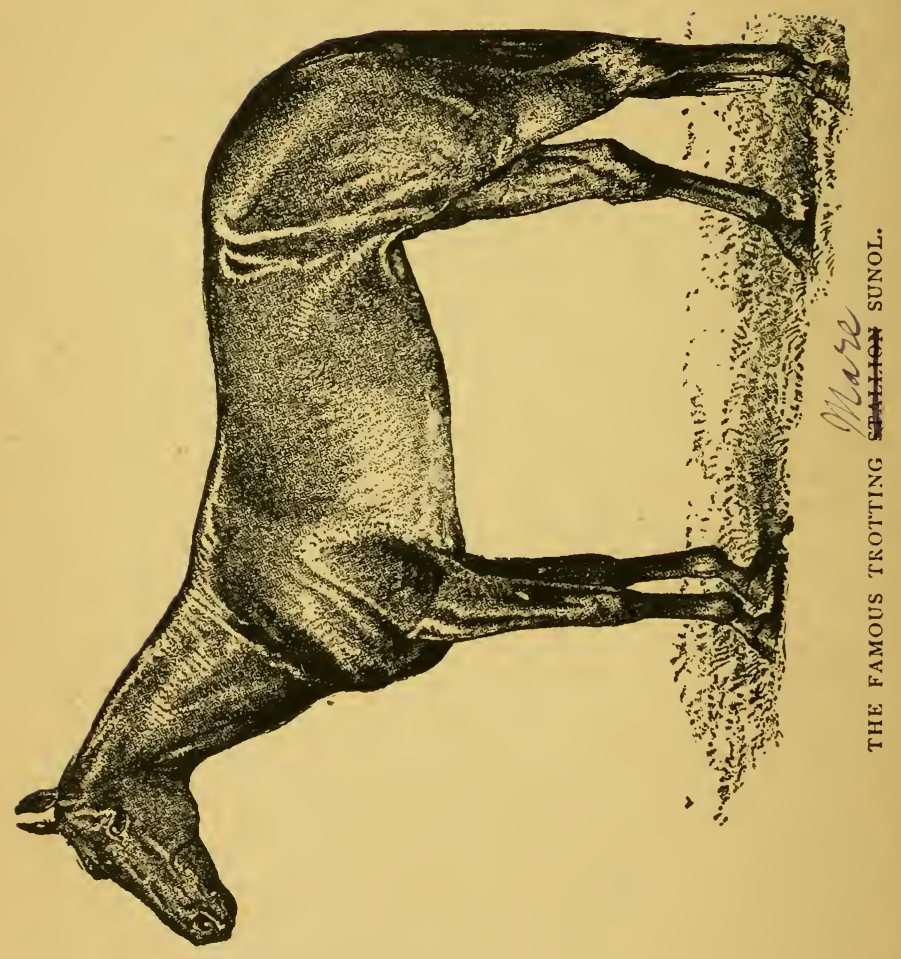


make the produce sure, which it takes the uninitiated a long time to find out, and which many American breeders have not yet discovered."

Then those who, tired of experiments, have begun to follow out certain inevitable laws in mating, are those who have met with success?

"Yes, and proud of it they may well be! They alone have saved the vanishing reputation of the American trotter."

Do we not export our trotting-horses?

"Once in a while a phenomenal trotter with a wide reputation is sent over to the other side; but they are not exported as a type, or to take the first place in a stud of thoroughbreds, although they are universally admired."

But only lately the Czar of Russia asked Governor Stanford for an exchange of trotting mares with his Russian Orloffs. Would not both countries be mutually benefited by such an exchange?

"If fine trotting mares are sent from America the Czar may get the best of the bargain, or as a Russian saying goes, 'He will have the hatchet, and we shall get the handle." "

Are the Orloffs trotters?

"Yes, madam, but their gait is very different from that of the American trotter. When the Orloff trots he leaves always a certain distance between his hind and fore-legs The American trotter throws his hind legs ahead of his fore-legs at every step, his hind legs being of abnormal length. The step of the Orloff is more graceful, inherited directly from the best of the Turcoman horses." 


\section{CHAPTER XXVI. \\ “STANDARD BRED" HORSES.}

Do we not export other animals than horses?

"Yes, certainly, hogs in barrels and butchered bullocks in ice, if you will kindly excuse the bluntness of the statement. With all the vast and unparalleled facilities in this magnificent country for growing live stock-which it is estimated can be done ninety per cent. cheaper here than in any country in Europe-America exports no animals except as they go to be butchered."

Can this be true, Count?

"Ah, madam, if you will read the statistics you will see that it is by the continued annual importation of breeding stock from England and Scotland that the cattle in the great West do not deteriorate. Is it to the credit of this great continent, with its vast grazing lands, its fertile valleys, its unlimited supply of fresh spring water, its spreading shade trees, its beneficent if changeable climate, that we import, in almost all cases, our thoroughbred animals instead of mating properly, and breeding intelligently, and so creating types of our own?"

Then it is true that we pay from five to seven millions of dollars annually to France and England alone for the importation of brood-stock? 
"Yes, those are the figures. The type is destroyed here at once by crossing, and dealers abroad profit by this continued mistake-the destruction of the types-and are therefore not averse to its encouragement, so long as their animals continue in demand. As soon as the various types of English horses are brought over, they are mongrelized by constant crossings, and thus the type cannot be sustained."

Do you know, Count, that England is to be represented by seven different types of horses at our World's Fair Exposition at Chicago in 1893 ?

"Ah, yes, England will be well represented there in that matter; for she sends not only her horses, but her sheep, cattle, hogs, and fowls all over the world for brood purposes. Her different families of thoroughbreds, all created from the Arab blood, are in demand by every other civilized nation for the purpose of creating new and perfect types."

Well, Count, I wonder if you can guess how many types of American horses are to be represented at our World's Fair in 1893 ?

"Madam, you puzzle me by such a questionplease explain."

The World's Fair Commission allows fourteen classes of horses for awards. Of these classes seven are of English created types, three of French, one of Belgian, one of German, all created from the Arab, and one from the Shetland Isles. The one that is left is to be devoted to the American "Standard-bred." To all our great, free, boundless, boasting Yankee nation, we are entitled to, and I suppose satisfied with, one kind of horse. I could hardly believe my 
own eyes when I read the little pamphlet which told of this remarkable distribution of honors and awards.

"But, madam, there is but one horse in America which approaches a type, and that is the 'Standardbred." "

\section{And how does the term come?}

"It is entirely arbitrary. No American horse can be entered at the Columbian Exposition unless he be 'Standard-bred' according to the register, and for the privilege of entry his owner must pay so much."

Is there not strong indignation at this injustice to other classes?

"Undoubtedly, and praiseworthy efforts are being made by horsemen to change a rule "better honored in the breach than in the observance." "

What is the real meaning of the term "Standardbred?"

"It means that the only excellence in the horse considered necessary is speed at an established rate. If he can trot in $2: 30$ he is entitled to be considered 'Standard-bred,' or, if having been gambled in races, he has beaten some other horse, he may aspire to the dubious distinction."

Then it describes no type; it belongs to no family; it can prove no ancestry?

"What you say is all true, madam."

Well, one might as well say a cow is "Standardbred," when she gives fifteen quarts of milk a day, and is not so when she fails to give so much. Or, that a dog is no setter unless he makes so many points an hour. The name must include many horses that are not desirable, and exclude many 
others who deserve not to be thus humiliated. So the distinction of being "Standard-bred," according to an arbitrary register, cannot be flattering to our national pride.

"After all, madam, it is only a convenient term adopted for want of a better, and to cover possibly many deficiencies. Breeders and owners will want to exhibit such horses as show the true virtues of noble descent, so doubtless the World's Fair Commissioners will realize the justice of this before it is too late." 


\section{CHAPTER XXVII.}

GENERAL GRANT'S HORSES.

I HAVE understood that Governor Stanford believes with Mr. Bonner that thoroughbred blood in the trotter is the essential which makes and breaks records; that cold blood has not the staying quality of thoroughbred blood, and that an infusion of it is necessary to give suppleness to the knee joints, as well as many other qualities which are desirable.

"Governor Stanford has been highly successful with the scientifically bred, and carefully reared, members of his stud. It is said that California, particularly that part of it subject to the invigorating coast winds, is destined to become the horse-kreeding district of the nation. That in California, with its twelve months' freedom from such inclement weather that horses need not be closely stabled, not losing, as they do elsewhere, four or five months of fresh air and regular exercise, all the equine aristocracy of America will be found sooner or later."

Do Governor Stanford, Mr. Bonner, and others breed only trotting horses?

"Undoubtedly the horse most in popular favor here is the trotting horse. If he can trot in $2: 30$ so much the better, for then he is sure to have undisputed sway as a race-horse, especially in the small West- 


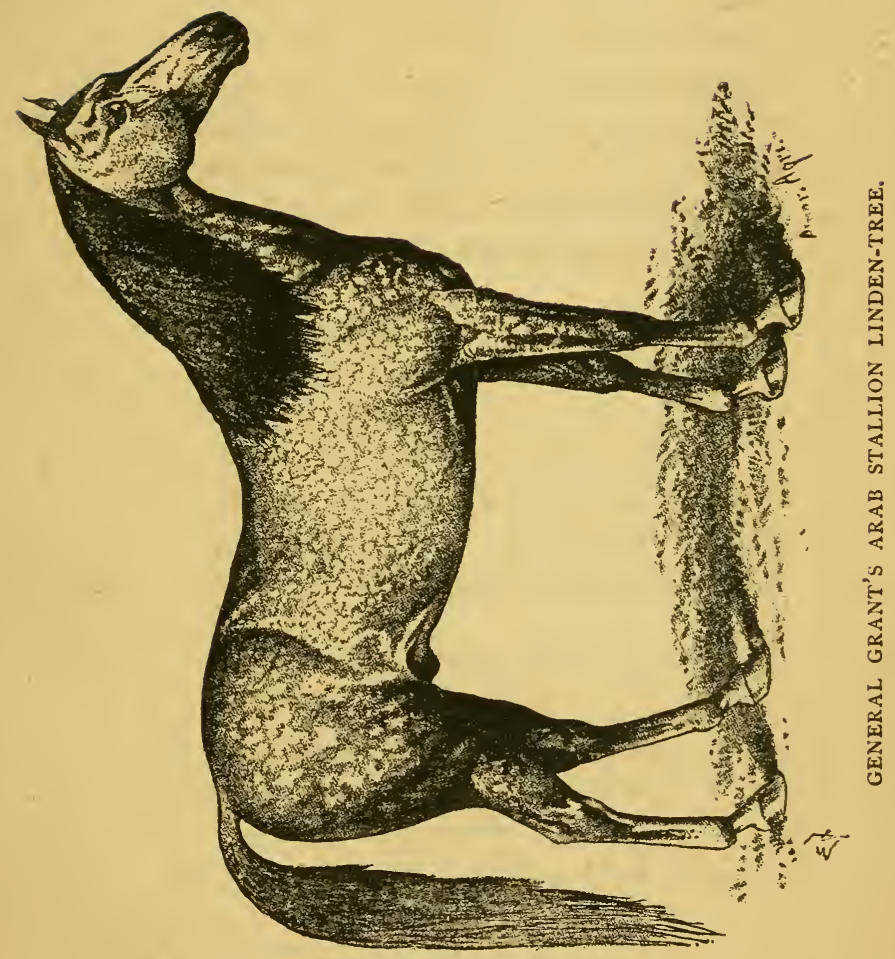


ern towns. Here and there I have discovered a horse with excellent blood lines, in the most obscure places. Only the other day, in this almost deserted village, I was attracted by the step and air of a little black mare pulling a butcher's cart. Falling into conversation with her owner, the butcher, I took a quick mental survey of the mare, and was convinced that she only needs proper training to do a day's work at fast trotting, which means one hundred miles in ten consecutive hours."

Have you ever known a horse to make such time as that?

"Yes, I knew of one who had no special record, who travelled one hundred miles in nine hours and fortyfive minutes. That is where the Arab will always win over the English thoroughbred. The latter may outrun the Arab, in the races for which he has been trained, but when the thoroughbred begins to show signs of fatigue the Arab is just 'getting down' to work."

I wonder did the butcher know what a prize he possessed?

"He seemed to have not the least idea of it, although he said 'she was a good little mare,' but he knew nothing of her ancestry."

The light harness-horse of America has a' great many admirers.

"Yes, and deservedly so. When properly broken and trained they make fine and valuable specimens of equine beauty."

Have they special blood-lines?

"When carefully bred from thoroughbred sires 
and dams their blood-lines are distinctive. They again prove the blood cause and for general worth and utility have few rivals."

Have many Arabian horses come to us since the close of the war?

"You have heard of course, of Leopard and Linden Tree presented to General Grant by Abdul Hamid, the Sultan of Turkey? No American was more fully alive to the fact of the sad reduction in numbers and quality of American horses during the war; and no man ever lived who more dearly loved a good horse than General Grant. His acceptance of the Arabs was in a great measure influenced by their special worth in the stud, realizing that the race must be rebuilt."

Did you not say, there was some doubt, about General Grant's horses, being the true-bred sons of the desert?

"There has often been such a doubt expressed."

Possibly General Grant's letter to Mr. Huntington on the subject may convince the unbelieving, and I am glad to be able to show it to you.

Did he ever drive these horses?

"They were possibly not broken to harness, but if so, he denied himself a great pleasure, and the immediate disposal of Leopard to General Beale and of Linden to his son, showed his interests and confidence in the infusion of Arab blood. He hoped that from them a new and better type of horse might be created. They are the only Arab stallions now in America, it is said, and their progeny are a most distinctive and superior type." 


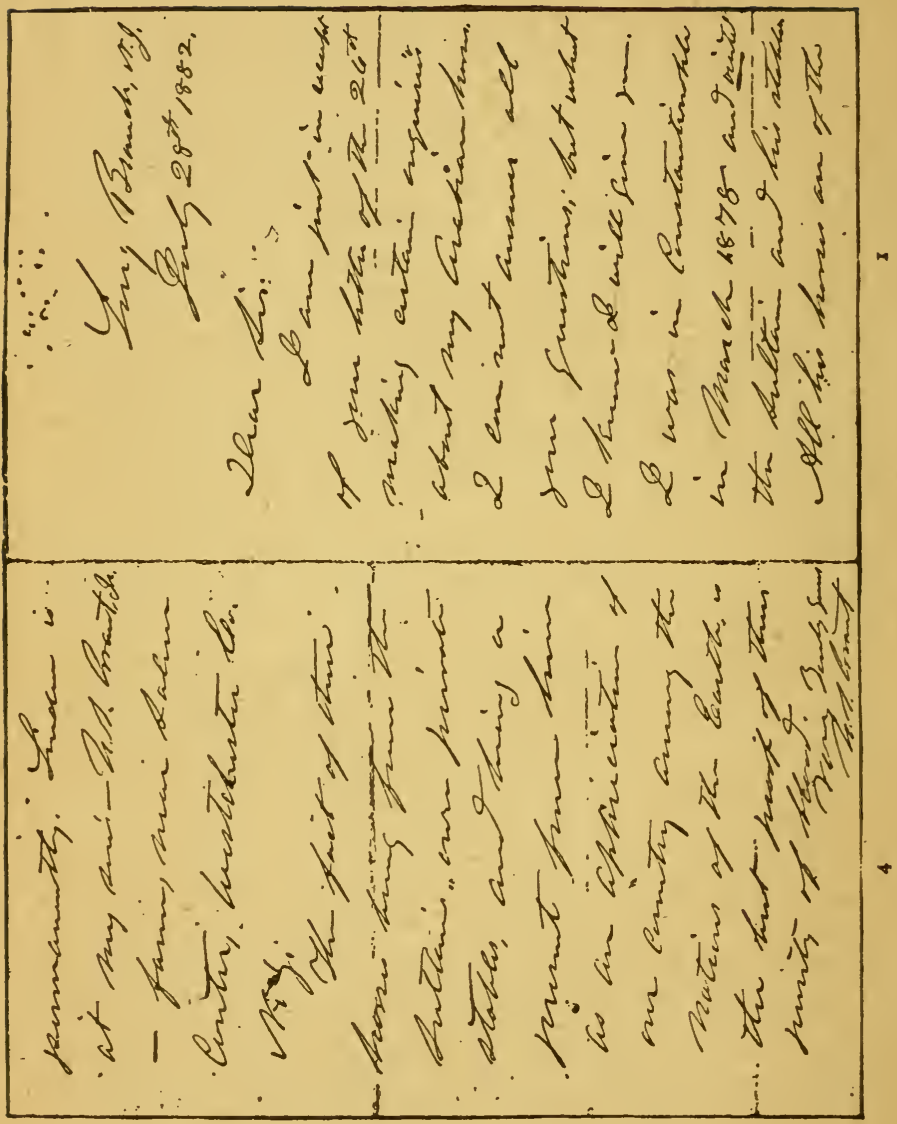




\section{CHAPTER XXVIII.}

\section{AMERICO-ARAB STUD.}

You have doubtless visited the stud on Long Island where this family of Americo-Arabs is bred?

"Only a few weeks ago I was there and examined with great interest, the various members of this unique family. Some of them were very handsome animals."

The beautiful mare, Naomi, and her filly, RuthClay, were there?

"Certainly. Naomi is said to be the only Arab mare ever imported to this country, no record of any other having been found."

It was with great difficulty and only through the influence of powerful friends in Europe that the president of the company succeeded in importing and securing Naomi.

"Yes, her arrival was a happy event, as Mr. Huntington believes that the Arab is primitive and perfect, and reproduces himself with all mental and physical perfection; that all of our values in the horse, whether to trot, pace, or run, come from the Arab, and that all good qualities are less or greater, according to the amount of good Arab blood. Crossings are but the dilution of blood cause. He realized the necessity of having more pure Arab 
blood, especially in the female line, that a promiscuous use of it is not satisfactory, and that an affinity blood is essential."

Then he adopted the methods employed in the Old World?

"Exactly so, and as here the Clay, Morgan, and Gold-dust families are strongest in the Arab blood, he selected virgin mares to mate with General Grant's Arabs, and was fortunate in the get of one filly and three colts. While these were growing he interbred these three families, getting a harem of fillies which at maturity he mated with the sons of Leopard and Linden Tree. The result was the foundation of a superb stud of thoroughbreds."

Why do they refuse to sell these horses?

"Because it is desirable to have a family so large that it can reproduce itself, then the annual sales need not weaken the strength of the plant. By close breeding with this Arab blood, the animals he might sell in the one blood will be so near to the primitive, that the improved results will be positive, and will, therefore, benefit any community into which they may be introduced."

Then the object of this company is to breed such perfect horses from the Arab as to elevate the bloodstandard in the United States.

"You have said it, madam, and it can only be regarded as a national triumph to breed a pure type that shall with certainty reproduce itself in any country, and to perpetuate it until it shall be known, recognized, approved, and earnestly sought for by every other nation as the American horse." 
Did you see any of the direct progeny of General Grant's Arabs, Count?

"Abdul Hamid II., a golden sorrel, and Abdul Hamid III., a bay, are a son and grandson of Leopard. Although Leopard and Linden are grays strange to say, none of their progeny are gray. Abdul Hamid III. was from an own sister to the dam of his sire, Abdul Hamid II. Both these stallions are much larger than their sire and grandsire, Leopard. Their dams were Mary and Topsy Shepard, by Jack Shepard, a son of Henry Clay, from a granddaughter of imported Messenger. The heads of this Leopard family are uniformly fine and clean, with straight faces Their limbs show their good blood, and their hocks are clean, as if chiselled from marble. They show fine trotting action, all to the credit of their sire, Leopard."

Is Linden's produce there also?

"Hegira, by Linden, was from a daughter of Henry Clay. This horse stands fifteen and one-half hands high barefoot, and is a rich, dapple coal-black. Linden was purchased by Abdul Hamid II., Sultan of Turkey, from an Egyptian merchant. It is said that all of the Sultan's Arabs are either seized by his tax-gatherers, or purchased by their agents. Hegira, by Linden, represents entirely different blood, from the get by Leopard. The head is shorter, finer in the muzzle, deeper and broader between jowls, dished in the face, with great breadth between the eyes. The ears are shorter and finer, the rump more sloping, showing all the characteris- 
tics of the pure Barb, a special family descending from the Numidian horse, also an Arab.

"Euphrates, a son of Hegira, from Mary Shepard, is the counterpart of his sire in build and color; but is phenomenal in that even at a walk he takes the pacing step. This inclination to pace is shown in all the get of Hegira, although he is a square-gaited trotter; and from the beginning of these special breedings no horse or mare was ever known to pace until Euphrates set the fashion.

"The sire of Clay Truth, a game and resolute trotter with a delightful disposition, was Ashland by Henry Clay. His dam was interbred to the blood of Justin Morgan, the Arab founder of the Morgan family.

"A horse showing fine trotting speed is Young Jack Shepard by Jack Shepard, by Henry Clay and from Kate McPherson, by Henry Clay. He is a beautiful dapple gray."

Where was Henry Clay born?

"He was born on Long Island, not far from where the Arab, Anglo-Arab, and Clay Stock Farm Company is located. In this collection is the only daughter of Henry Clay now living, not too old to produce; while the interbred sons and daughters have come back to Long Island, to restore to her, the prestige she lost, when all the blood of Andrew Jackson (the Anglo-Arab bred sire of Henry Clay) was sold away from it."

But you have told me so little, Count, of the Arab mare, Naomi.

"There is no doubt whatever of the absolute 
purity of Naomi's blood. The late Captain Roger Upton, of the English Army, who lived frequently among the Arabs, and was an enthusiast about pure horses, himself purchased both her parents at great cost from the Gomussa tribe, in the Euphrates valley. Naomi was foaled a few days after their arrival in England. Her sire was Yataghen, 14.3, and her dam Haidee, also 14.3. Both these were Maneghi, considered in the desert the choicest of all families. They have, as a rule, finer action, and if. possible, a greater amount of wear and tear in them. On the other hand, they are a little larger and coarser in the head sometimes, than, for instance, the Seglawi Jedran. An alliance between the last-named family and the Maneghi is simply perfect, so far as blood goes. Owing to the system of Naomi's rearing she is the largest pure Arabian I have seen, being $15 \frac{1}{2}$ hands high."

English breeders did not relish the idea of her being sent here, I've heard.

"No, but her owner, the Rev. F. F. Vidal, of Suffolk County, England, was so interested in the efforts of this company to breed pure Arabs (and because of his illness induced to relinquish his stud) that he at last listened to the petitions for her and sent her over. Her colt, Gomussa, now in Chili, was by Kouch. All race-horsemen in America, as well as England, know that the opinion of the celebrated jockey, Fred Archer, was of great value. He rode Kismet in his English races, and pronounced him the gamest horse and best finisher of a race he had ever ridden." 


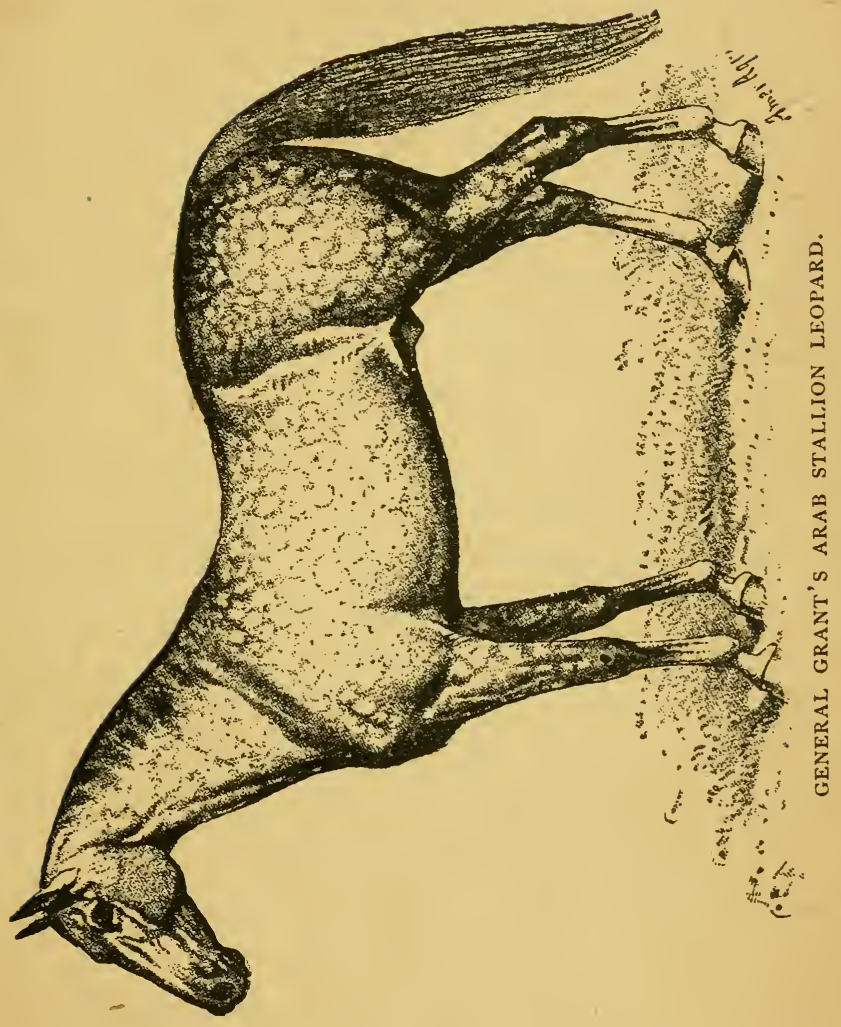


What get has Naomi here?

"Since coming to this country she has produced the beautiful colt, Anazeh-now two years old-by General Grant's Leopard. This gives Anazeh the distinction of being the first pure-bred Arabian horse born in the United States, both sire and dam being imported as the true 'air-drinkers of the desert.' In I 890 the dainty filly, Ruth Clay, was born, whose sire is Jack Shepard. Ruth Clay roams with her mother, Naomi, without bridle or halter, as tame as any dog, about the unfenced grounds surrounding her master's house. They both expect caresses and come for them with a little air of curiosity toward a stranger, that partakes not in the least of feat Naomi has all the dignity of aristocratic birth ana associations, walking up to you as sedately as you please, to have her pretty face stroked. When a lump of sugar is not in evidence, Ruth pokes her dainty muzzle about her mistress' skirts to find her pocket, and the sugar dropped within it. She is playful, alert, coquettish, and full of mischievous pranks, and like her dam, bids fair to remind one of the quotation, 'In her, strength and beauty have come together,' and all the pride of all her race, in herself reflected lives." 


\section{CHAPTER XXIX.}

CONCLUSION.

IN all my conversations with the Count little has been said about the inevitable effects of climate on all races of men and animals. It is so interesting a study, that many chapters might be needed to do justice to the subject. A few words now regarding it may not be amiss.

That climate makes and unmakes different types of races in man, is a conceded fact, even to a complete change of form and feature. The dark, glowing eyes of the fervid South, after two or three generations, become blue or gray with softer lights, when transplanted to the North, and the hair, black as night, turns to tender brown or shining gold. Owing to the different conditions of climate another type is being evolved, and even the nature and disposition are undergoing a radical change.

In England, the mild-tempered climate tends to round out the form, and to give a reddish glow to the face. To expect the same type in France, only across the channel, would be absurd, or to mistake an Italian for a German would be laughable. The climate in these countries is pronounced, and so are the types. With our entirely uncertain climate who can be sure of any distinct type in America? We 
have our class distinctions, our various social levels, our families, proud of their American ancestry; and to serve us all, we import from every country under the sun. IVe are always importing distinct types of live stock, both of man and beast, and our importations "come to stay." But even after many yearsbeyond the "je ne sais quoi," which betrays our nationality - who can assert that America has a type? Do we owe this fact to our ever changing ciimate, which woos us with coquettish smile, caressing our expectant cheeks with balmy breezes from the Sunny South, and embracing us in a loving, generous warmth one day, and the next! with blackest f:own; pelts us unmercifully with wind and storm, hail and rain, with terrifying thunder which roars at us, and angry lightning which strikes and blinds and destroys us? With nothing positive in the way of climate, our differing types have no chance to become fixed, and the student who loves to arrange and classify will yield the attempt in despair.

When we import a horse of whatever type, after two or three generations hi.s progeny loses his distinctive marks, and in two or three more the climate has obliterated any that might be left. Some three hundred years ago when the Spanish horses entered America, some of them escaped to the great plains of the West. From them has been evolved the native horse of America, the broncho. The conditions of climate have made him what he is, strong, rough, and hardy; able to exist on the scantiest of food, in the severest weather. He would probably turn up his nuse at a "warm mash," thinking it "food for 
babes," and would no doubt resent a daily grooming as an unwarranted liberty. He remains a savage, and as a savage cannot always be trusted. But when he is caught and fairly tamed, he can do more hard steady work in a day, than the pampered, petted stabled horse of the East, could do in three. This broncho is our national type, evolved by the climate of the plains, and in direct contrast to the tame, gentle, and affectionate Arab, reared in the wilds of the scorching unprotected desert. Small in size, they are both hardy, enduring, and able to travel great distances without fatigue and here the two extremes of climate, seem to develop similar characteristics of endurance. When we can control our climate we may be able to develop fixed types; but until then it must be our excuse, that something different from what we so often expect, appears.

The shrewdest and most thoughtful observers and students of animal life are frequently those, who give not to the doubting world the benefit of their wisdom and experience. Too often they are misunderstood and any facts that seem strange and new, and yet are as old as the memory of man, are received with doubt, contempt, and ridicule. In a way we Americans are a self-satisfied, self-sufficient people, proclaiming our patriotic love for our newly-founded institutions, by ignoring the wisdom gained in the O1d World, through centuries of practical experience. Many things that we have never thought about at all, or that are just beginning to present themselves to our intelligence, have occupied the close attention of foreign governments for hundreds of years. Facts 
are stubborn things, and cannot be obliterated by any amount of denial or argument. The Austrian, French, Russian, German, Italian, and other European goverments have studied deeply, the blood cause in horses, and having a wide and comprehensive faith in their own methods, naturally look with disdain upon ignorant and unscientific breeders.

The English have admired always what is not English, with a "saving clause," and when the American çolonists, more than a century ago, asked for their freedom from English rule, it was refused with the intimation that they were not capable of self-government. This sneer lost John Bull his colonies, and America then and there declared her independence to act as she pleased. She has done so ever since, not always admitting, that in some things, other nations might be wiser. But to-day, in matters of science she recognizes the imperative necessity of a training that educates, compares, observes closely, avoids serious mistakes, and produces the inevitable consequences desired or intended. It is one of the blessed results of our swift Trans-Atlantic journeys, encouraging constant travel and communication with foreign countries, that the wise of our day and generation have been enabled to gather and enjoy the various fruits of scientific research, ripe with age, to be found in the cultivated gardens of Europe's colleges.

The recent establishment here of veterinary schools is a growth commensurate with the more advanced ideas, not only of men of science, but of such interested owners of blooded stock as desire to 
perpetuate the best types, and who are willing to experiment only in the right direction. Only a few years ago the "vet" in America was the stableman, practised only in his daily care of, and experience with, horses, and seeking to relieve their distress through his very love of them. To-day a thorough course of study and practical training is deemed essential, to secure a graduate's diploma in any veterinary college. The American Veterinary Review, issued monthly, edited by Prof. A. Liautard, M.D., V.M., Honorary Fellow of the Royal College of Veterinary Surgeons, England, and the valuable works of Dr. James Law, of Cornell University, Prof. O. Schwartzkopff, V.M:, of the University of Minnesota, Prof. Wm. Zuill, M.D., D.V.S., of the University of Pennsylvania, Dr. Hoskins and Dr. Williams of New York, Dr. Huidekoper of Philadelphia, Dr. D. E. Salmon of the U. S. Department of Agriculture, and others, tell of the great strides in practical scientific knowledge our students are making.

To seize an idea quickly and improve it to perfection is a national trait-a matter of chronic surprise and wonderment, to those who know only the method which grinds and plods, to arrive at certain truths only after the most exhausting labor.

If our experiments are somewhat bold, we are sure they will be tempered with humane treatment, and that we shall never imitate the dreadful abuses one sometimes reads of in the foreign news, to which science in many cases condemns its victims, the wretched dumb creatures selected for experiment.

Our societies for the prevention of cruelty to 
animals, presided over by such men as George Angell of Boston and John P. Haines of New York, are ever on the alert to enforce kindest consideration for all that need their protection, while cruelties are punished with all the rigors of the law. The workers are in earnest. Abuses are being corrected. The abolishment of the check-rein in many of the smartest turn-outs on our fashionable drives, proves the significance of "Black Beauty's" horse-sense, and how deeply it has sunk into the minds and natures of the hitherto unthinking. That they follow the example set by the Queen of England, who permits no check-reins, does not detract from the courage of refusing here, to follow a fashionable fad.

All domesticated animals crave a perfect sympathy with their masters, and ask in their mute way for some constant expression of it. Wlıat lover can exhibit a more genuine jealousy than a devoted dog, or show the symptoms of that unhappy trait more determinedly? What a tragical grief is that which can make a dog or horse refuse his food, and thus die of starvation, for the loss of his companion for whom he had such enduring love? Such instances are numerous. Horses are never so willing, as when they feel the magnetic influence of the hand that guides, and the voice that cheers them on! So intense is this sympathy that they become easy subjects of hypnotization. The practice of this mysterious science was introduced into the Austrian army by a cavalry officer named Balassa, and hence is called "Balassiren." So popular has it become in cases 
of any painful operation, that it has been adopted by law in Austria.

What the years may bring forth to us in our intimate and ever extending knowledge of the superlative delight and usefulness of our coming horse, may all my indulgent readers live to know and appreciate! And if this little book shall point the way to improvement in any direction, it will have fulfilled its intended mission. 




